\title{
Mexico City aerosol analysis during MILAGRO using high resolution aerosol mass spectrometry at the urban supersite (T0) - Part 1: Fine particle composition and organic source apportionment
}

\author{
A. C. Aiken ${ }^{1,2, *}$, D. Salcedo ${ }^{3}$, M. J. Cubison ${ }^{2}$, J. A. Huffman ${ }^{1,2}$, P. F. DeCarlo ${ }^{2,4, *}$, I. M. Ulbrich ${ }^{1,2}$, K. S. Docherty ${ }^{2}$, \\ D. Sueper ${ }^{2,5}$, J. R. Kimmel ${ }^{2}$, D. R. Worsnop ${ }^{5}$, A. Trimborn ${ }^{5, * *}$, M. Northway ${ }^{5, * * *}$, E. A. Stone ${ }^{6}$, J. J. Schauer ${ }^{6}$, \\ R. M. Volkamer ${ }^{1,2}$, E. Fortner ${ }^{5,7,8}$, B. de Foy ${ }^{9}$, J. Wang ${ }^{10}$, A. Laskin ${ }^{11}$, V. Shutthanandan ${ }^{11}$, J. Zheng ${ }^{8}$, R. Zhang ${ }^{8}$, \\ J. Gaffney ${ }^{12}$, N. A. Marley ${ }^{12}$, G. Paredes-Miranda ${ }^{13}$, W. P. Arnott ${ }^{13}$, L. T. Molina ${ }^{14}$, G. Sosa ${ }^{15}$, and J. L. Jimenez ${ }^{1,2}$ \\ ${ }^{1}$ Department of Chemistry, University of Colorado at Boulder, 215 UCB, Boulder, CO 80309, USA \\ ${ }^{2}$ Cooperative Institute for Research in the Environmental Sciences (CIRES), University of Colorado at Boulder, 216 UCB, \\ Boulder, CO 80309, USA \\ ${ }^{3}$ Centro de Investigaciones Quimicas, Universidad Autónoma del Estado de Morelos, Cuernavaca Morelos, Mexico \\ ${ }^{4}$ Department of Atmospheric and Oceanic Sciences, University of Colorado at Boulder, UCB 311, Boulder, CO 80309, USA \\ ${ }^{5}$ Aerodyne Research Inc., 45 Manning Rd., Billerica, MA, 01821, USA \\ ${ }^{6}$ Environmental Chemistry and Technology Program, University of Wisconsin-Madison, 660 North Park St., Madison, \\ WI 53706, USA \\ ${ }^{7}$ Montana State University, Bozeman, MT 59717, USA \\ ${ }^{8}$ Texas A\&M, 3150 TAMU, College Station, TX 77843, USA \\ ${ }^{9}$ Saint Louis University, St. Louis, MO 63108, USA \\ ${ }^{10}$ Brookhaven National Laboratory, P.O. Box 5000, Upton, NY 11973, USA \\ ${ }^{11}$ Pacific Northwest National Laboratory, Richland, WA, USA \\ ${ }^{12}$ University of Arkansas, 2801 S. University Avenue, Little Rock, AR 72204, USA \\ ${ }^{13}$ University of Nevada Reno and the Desert Research Institute, Reno, NV, USA \\ ${ }^{14}$ Molina Center for Energy and the Environment and Massachusetts Institute of Technology, USA \\ ${ }^{15}$ IMP, Eje Central Norte Lazaro Cardenas 152, Mexico City, DF 07730, Mexico \\ *now at: Institute for Atmospheric and Climate Science, Swiss Federal Institute of Technology Zurich (ETH-Zurich), \\ 8092 Zurich, Switzerland \\ ${ }^{* *}$ now at: Paul Scherrer Institut, 5232 Villigen-PSI, Switzerland \\ *** now at: Department of Meteorology, University of Reading, Reading, UK
}

Received: 14 February 2009 - Published in Atmos. Chem. Phys. Discuss.: 30 March 2009

Revised: 7 August 2009 - Accepted: 15 August 2009 - Published: 11 September 2009

\begin{abstract}
Submicron aerosol was analyzed during the MILAGRO field campaign in March 2006 at the T0 urban supersite in Mexico City with a High-Resolution Time-of-Flight Aerosol Mass Spectrometer (HR-ToF-AMS) and complementary instrumentation. Mass concentrations, diurnal cycles, and size distributions of inorganic and organic species are similar to results from the CENICA supersite in April 2003 with organic aerosol (OA) comprising about half of the
\end{abstract}

Correspondence to: J. L. Jimenez (jose.jimenez@colorado.edu) fine PM mass. Positive Matrix Factorization (PMF) analysis of the high resolution OA spectra identified three major components: chemically-reduced urban primary emissions (hydrocarbon-like OA, HOA), oxygenated OA (OOA, mostly secondary OA or SOA), and biomass burning OA (BBOA) that correlates with levoglucosan and acetonitrile. BBOA includes several very large plumes from regional fires and likely also some refuse burning. A fourth OA component is a small local nitrogen-containing reduced OA component (LOA) which accounts for $9 \%$ of the OA mass but one third of the organic nitrogen, likely as amines. OOA accounts for almost half of the OA on average, consistent with previous

Published by Copernicus Publications on behalf of the European Geosciences Union. 
observations. OA apportionment results from PMF-AMS are compared to the $\mathrm{PM}_{2.5}$ chemical mass balance of organic molecular markers (CMB-OMM, from GC/MS analysis of filters). Results from both methods are overall consistent. Both assign the major components of OA to primary urban, biomass burning/woodsmoke, and secondary sources at similar magnitudes. The 2006 Mexico City emissions inventory underestimates the urban primary $\mathrm{PM}_{2.5}$ emissions by a factor of $\sim 4$, and it is $\sim 16$ times lower than afternoon concentrations when secondary species are included. Additionally, the forest fire contribution is at least an order-of-magnitude larger than in the inventory.

\section{Introduction}

Ambient aerosols are of interest due to their effects on human health, regional visibility, and climate (Watson, 2002; Pope and Dockery, 2006; IPCC, 2007). As the number and fraction of the global population living in megacities (defined as having $>10$ million people) are increasing, the effects of megacity aerosols on human health, in addition to downwind chemistry and radiation (Madronich, 2006), are becoming more important. Most megacities are located in the tropics, while most atmospheric chemistry field research has been conducted in the mid-latitudes. The MILAGRO project (Megacity Initiative: Local and Global Research Observations) is the first large-scale field campaign that focuses on a tropical megacity (Molina et al., 2008) and follows smaller campaigns carried out in Mexico City such as IMADA-AVER (Edgerton et al., 1999) and MCMA-2003 (Molina et al., 2007).

The Mexico City Metropolitan Area (MCMA) is the largest megacity in North America and is one of the five largest cities in the world with over 20 million people in $\sim 1500 \mathrm{~km}^{2}$. The MCMA has a history of severe air quality problems due to a large number of pollution sources with uneven levels of emission control, which can be further exacerbated by the topography and meteorology of the basin (Molina and Molina, 2002). The tropical location $\left(19^{\circ} \mathrm{N}\right)$ and high altitude ( $2240 \mathrm{~m}$ above sea level) result in high UV fluxes and intense photochemistry. The basin is surrounded by mountains on three sides, reducing ventilation of pollutants, especially at night and in the early morning. However, the boundary layer grows to several $\mathrm{km}$ above ground, where wind speeds tend to be larger, resulting in significant daily ventilation and limited overnight accumulation or pollutant recirculation (Fast and Zhong, 1998; de Foy et al., 2006b, 2009). Basin ventilation patterns are strongly influenced by a gap flow which forms a convergence line over the MCMA (Whiteman et al., 2000; de Foy et al., 2006a). A classification of weather patterns based on the wind shift and convergence line found three characteristic episode types during MCMA2003 (de Foy et al., 2005), which was expanded to six for MILAGRO (de Foy et al., 2008).
The MCMA-2006 campaign, a component of MILAGRO, focused on measurements within the basin to better quantify emission sources, photochemistry, and air circulation in the basin. Figure S-1 in the Supplemental Information (see http://www.atmos-chem-phys.net/9/6633/2009/ acp-9-6633-2009-supplement.pdf) shows the location of the major measurement sites during the campaign. The T0 Supersite was located $9 \mathrm{~km} \mathrm{NNE}$ of the city center and $16 \mathrm{~km}$ NNW of the CENICA (Centro Nacional de Investigación y Capacitación Ambiental) Supersite used during MCMA2003. Besides providing a local characterization site for urban pollution, T0 was also designed to provide initial conditions for regional evolution studies of the urban plume (e.g. DeCarlo et al., 2008; Kleinman et al., 2008).

Fine particulate matter (PM) is one of the most serious air quality problems in Mexico City (Molina et al., 2007). Previous campaigns have concluded that about half of the fine PM is organic aerosol (OA) (Chow et al., 2002; Salcedo et al., 2006). OA has numerous sources and can be classified as either primary OA (POA), material directly emitted as particles, or secondary OA (SOA), species formed in the atmosphere via chemical reactions (Hallquist et al., 2009). Data from MCMA-2003 indicated the importance of secondary inorganic (i.e. ammonium nitrate) and organic (SOA) production within the city and their resultant large contributions to the fine PM concentrations (Salcedo et al., 2006; Volkamer et al., 2006, 2007; Dzepina et al., 2009). These results are consistent with those from other locations (Zhang et al., 2005c; Lonati et al., 2007; Weber et al., 2007; Zhang et al., 2007a; Docherty et al., 2008; Fine et al., 2008), and the importance of SOA as a fraction of PM is again apparent during MILAGRO (DeCarlo et al., 2008; Herndon et al., 2008; Kleinman et al., 2008; Stone et al., 2008; de Gouw et al., 2009; Paredes-Miranda et al., 2009; Fast et al., 2009; Hodzic et al., 2009). For example, Kleinman et al. (2008) and de Gouw et al. (2009) report a growth in the $\mathrm{OA} / \Delta \mathrm{CO}(\mathrm{g})$ ratio with photochemical age due to SOA formation that is consistent with previous observations in the US (e.g. de Gouw et al., 2005). Paredes-Miranda et al. (2009) report that on average the secondary species accounts for about $75 \%$ of the fine PM mass and light-scattering in the mid-afternoon, while Herndon et al. report a strong correlation between the observed growth of SOA and $\mathrm{O}_{\mathrm{x}}\left(\mathrm{O}_{3}(\mathrm{~g})+\mathrm{NO}_{2}(\mathrm{~g})\right)$. DeCarlo et al. (2008) report an $\mathrm{OA} / \triangle \mathrm{CO}$ for urban air that is much greater than that of primary emissions and a rapid increase in the $\mathrm{O} / \mathrm{C}$ ratio of OA with photochemical age, both indicating strong SOA formation from MCMA emissions. Based on comparisons with water-soluble OC, Stone et al. (2008) attribute the unapportioned OC from CMB-OMM as secondary OC for MCMA, resulting in 39\% on average of the OC (and thus a larger fraction of the OA) being secondary at T0. Fast et al. (2009) and Hodzic et al. (2009) report a large underestimation of the measured OA when only POA sources are considered, supporting the importance of SOA. 
The MCMA is also impacted by biomass burning (BB) emissions during the dry season (March-June, Bravo et al., 2002; Salcedo et al., 2006; Molina et al., 2007). During the later portion of the MCMA-2003 campaign, an important regional impact from fires in the Yucatan was reported (Salcedo et al., 2006; Molina et al., 2007). During part of MILAGRO, forest fires from pine savannas in the nearby mountains surrounding the city were very intense and resulted in a significant contribution to the outflow of pollutants from the Mexico City region (Yokelson et al., 2007; DeCarlo et al., 2008; Crounse et al., 2009). The relative impact of BB to ground receptor sites in the city appears to have been highly variable and lower than was observed aloft from several afternoon flights (Querol et al., 2008; Stone et al., 2008; de Gouw et al., 2009). The mountain fires tended to start around noon (Yokelson et al., 2007) and were often carried away from the city by the prevailing winds (Yokelson et al., 2007; DeCarlo et al., 2008; Crounse et al., 2009). Stone et al. (2008) report that an average of $12 \%$ (range 5-26\%) of the organic carbon (OC) in $\mathrm{PM}_{2.5}$ at $\mathrm{T} 0$ originated from BB sources, and that this impact was highly variable from day to day. Querol et al. (2008) estimate that the BB contribution to total $\mathrm{PM}_{2.5}$ at T0 was $\sim 5-15 \%$. Moffet et al. (2008a) report that $40 \%$ of the single-particles at the upper end of the accumulation mode showed signatures characteristic of biomass/biofuel burning but do not quantify the fraction of OA due to these particles. Fast et al. (2009) reports a large overestimation of OA downwind of some large wildfires by a model which only includes POA, suggesting that the POA emissions of at least some fires are overestimated. In summary, significant uncertainties still exist in determining the sources and contribution of $\mathrm{BB}$ within the MCMA basin.

In this paper, we present results from ground-based measurements inside the MCMA at the T0 Supersite, including: (1) an overview of the species contributing to submicron PM, their diurnal cycles, size distributions, and comparison with MCMA-2003 and IMADA-AVER results; (2) a determination of OA components using Positive Matrix Factorization (PMF) of high-resolution AMS data (PMF-AMS); (3) a comparison of PMF-AMS results with source apportionment results from the chemical mass balance of organic molecular markers (CMB-OMM); and (4) a comparison of our results with the MCMA PM 2.5 emissions inventory. The impact of biomass burning at $\mathrm{T} 0$ is analyzed in detail in the companion paper (Aiken et al., 2009).

\section{Methods}

\subsection{General}

Data were collected at the T0 Supersite, located at the Instituto Mexicano del Petroleo (IMP, $19^{\circ} 29^{\prime} 23^{\prime \prime} \mathrm{N}, 99^{\circ} 08^{\prime} 55^{\prime \prime} \mathrm{W}$, $2240 \mathrm{~m}$ altitude, $\sim 780 \mathrm{mbar}$ ambient pressure), $9 \mathrm{~km} \mathrm{NNE}$ of the city center, near a combination of residential, commer- cial and light industrial areas. The closest street with significant road traffic was $200 \mathrm{~m}$ from the site. Aerosol data were collected from the top of building $32, \sim 28 \mathrm{~m}$ above ground level, from 10 to 31 March 2006, unless otherwise stated. All aerosol data are reported in $\mu \mathrm{g} \mathrm{m}^{-3}$ at local ambient pressure and temperature conditions. To avoid confusion with concentrations reported in other studies that use standard conditions (STP), we use the units symbol of $\mu \mathrm{g} \mathrm{am}^{-3}$ to make it clear that the measurements are reported under ambient conditions. To convert to STP ( $1 \mathrm{~atm}, 273 \mathrm{~K}, \mu \mathrm{g} \mathrm{sm}^{-3}$ ), the particle concentrations reported here need to be multiplied by $\sim 1.42$. Note that some studies use different standard conditions from those mentioned above, e.g. Kleinman et al. (2008) reported concentrations under $1 \mathrm{~atm}$ and $293 \mathrm{~K}$ and that volume mixing ratios (ppbv, pptv, etc.) are invariant and do not depend on the pressure or temperature. All measurements are reported in local standard time (LST, equivalent to US CST and UTC minus $6 \mathrm{~h}$, and the same as local time during the campaign). All regression lines are fit by orthogonal distance regression.

\subsection{AMS sampling and analysis}

A High Resolution Time-of-Flight Aerosol Mass Spectrometer (HR-ToF-AMS, Aerodyne Research Inc., Billerica, MA) sampled from a common inlet using a $\mathrm{PM}_{2.5}$ cyclone (URG2000-30EN, URG, Chapel Hill, NC) at a flowrate of $\sim 10 \mathrm{lpm}$ through a $\sim 3 \mathrm{~m}$ insulated copper inlet line ( $1 / 2$ inch o.d.) located $\sim 5 \mathrm{~m}$ above the roof and $\sim 2 \mathrm{~m}$ above the roof structure where the instruments where housed. The total inlet residence time was 16s under laminar flow. A nafion drier (Perma-Pure, Toms River, NJ) was used to dry the air prior to sampling with the AMS. The HR-ToF-AMS (abbreviated as AMS hereafter) has been described in detail previously (DeCarlo et al., 2006; Canagaratna et al., 2007). AMS data were saved every $2.5 \mathrm{~min}$, combining total nonrefractory (NR) $\mathrm{PM}_{1}$ concentrations from the mass spectrum (MS) mode and size distributions from the particle time-offlight (PToF) mode (Jimenez et al., 2003). The main advantage of the HR-ToF-AMS over previous AMS versions (Jayne et al., 2000; Drewnick et al., 2005) is the ability to resolve the elemental composition of most mass fragments, especially for the low $\mathrm{m} / \mathrm{z}(<100)$ ions. The increased chemical information enables more direct chemical characterization of organic and inorganic species in addition to improved differentiation of organic components with tracer ions and factor analysis. The "V" and "W" ion paths of the AMS (DeCarlo et al., 2006) were alternated every 5 minutes, and this was the first campaign in which such alternation was performed automatically due to the newly developed ability to remotely control the TOF mass spectrometer power supply (TPS). Size distributions were acquired only in V-mode as their signal-to-noise in W-mode is limited. During different periods of the campaign, the AMS also intermittently sampled through a thermal denuder (Huffman et al., 2008, 
2009a, b), aerosol concentrator (Khlystov et al., 2005) or CCN selector (Osborn et al., 2008). The analysis here only includes the ambient data as the more specialized alternating data will be presented elsewhere. All data were analyzed using standard AMS data analysis software (SQUIRREL v1.43 and PIKA v.1.03E, Sueper, 2008) within Igor Pro 6 (Wavemetrics, Lake Oswego, OR). A collection efficiency (CE) of 0.5 was used for all data based on the observed composition and the composition-CE relationships observed in previous campaigns (Canagaratna et al., 2007), consistent with other recent studies in Mexico City and during MILAGRO (Salcedo et al., 2006, 2007; DeCarlo et al., 2008; Kleinman et al., 2008), and also consistent with the intercomparisons presented below. Elemental analysis of the OA was carried out with the methods described previously (Aiken et al., 2007, 2008). Positive matrix factorization (PMF, Paatero and Tapper, 1994; Lanz et al., 2007; Ulbrich et al., 2009) was conducted on unit mass-resolution (UMR) spectra and on the combined high mass resolution (HR, for $m / z \leq 100$ ) and UMR $(\mathrm{m} / \mathrm{z}>100)$ OA spectra as has been done previously (Docherty et al., 2008). Results from both analyses were similar, but the HR data showed improved separation, as expected given the increased differentiation of HR spectra for the different sources (Ulbrich et al., 2009). Therefore, only results of the PMF analysis including HR data are presented here. The identification of OA components from the AMS data provides high time resolution data and diurnal cycles not possible with source apportionment methods that require off-line analysis of filters.

\subsection{Co-located measurements used in this study}

Additional measurements were collected at $\mathrm{T} 0$ and are used in this analysis. A Scanning Mobility Particle Sizer (SMPS, Wang and Flagan, 1989) measured number distributions between 15 and $436 \mathrm{~nm}$ in diameter. Apparent volume distributions were calculated while assuming sphericity, which could lead to an overestimation of the actual volume in the presence of fractal particles from combustion processes (DeCarlo et al., 2004). Black carbon (BC) absorption measurements were made with an aethalometer (Marley et al., 2009). Hourly $\mathrm{PM}_{1}, \mathrm{PM}_{2.5}$ and $\mathrm{PM}_{10}$ mass concentrations were acquired with an optical particle counter (OPC)/laser spectrometer (Grimm) corrected by gravimetric measurements (Querol et al., 2008). Additional optical measurements, including light scattering and absorption, were made with a nephelometer (Marley et al., 2009) at $530 \mathrm{~nm}$ (scattering at $450 \mathrm{~nm}, 550 \mathrm{~nm}, 700 \mathrm{~nm}$ and absorption at $670 \mathrm{~nm}$ shown in Supp. Info.: http://www.atmos-chem-phys.net/9/ 6633/2009/acp-9-6633-2009-supplement.pdf) and a photoacoustic spectrometer (PAS) for light absorption and reciprocal nephelometer light scattering measurements at $532 \mathrm{~nm}$ (Paredes-Miranda et al., 2009). Two sets of filters and impactor samples were collected and analyzed: (1) elemental concentrations with 6-h time resolution using proton-induced
X-ray emission (PIXE; (Johnson et al., 2006, 2008); (2) organic molecular markers using gas-chromatography massspectrometry (GC-MS) from $\mathrm{PM}_{2.5}$ filter samples at 24-h resolution (Stone et al., 2008). The chemical mass balance of organic molecular markers (CMB-OMM) identified and quantified by GC-MS was applied to determine the contributions of various sources to OC (Stone et al., 2008). For comparison with the PMF-AMS results, OC was converted to $\mathrm{OM}$ using previously published $\mathrm{OM} / \mathrm{OC}$ values for the different sources (Turpin and Lim, 2001; Aiken et al., 2008).

Gas-phase measurements include $\mathrm{NO}_{2}, \mathrm{O}_{3}$, and aromatics by Differential Optical Absorption Spectroscopy (DOAS, Volkamer et al., 1998, 2005), and acetonitrile from two proton-transfer reaction mass spectrometers (PTR-MS, Zhao and Zhang, 2004; Knighton et al., 2007; Fortner et al., 2009). CO was obtained from the Mexico City ambient air monitoring network (RAMA, Red Automatica de Monitoreo Atmosferico, http://www.sma.df.gob.mx/simat/home base.php) station at IMP at one minute time resolution and compared well with intermittent data acquired by two other groups, D. Blake (UC-Irvine, personal communication, 2008) and M. Dubey (LANL; personal communication, 2008). Meteorological data, including temperature, relative humidity, precipitation, wind speed and direction, pressure, and precipitation were collected by Marley et al. (2009).

\section{Results}

\subsection{Total submicron aerosol - mass concentrations, time series, and size distributions}

First, we compare the sum of the chemically-speciated mass concentrations with co-located total fine PM instrumentation to establish the consistency of the different measurements at T0. The non-refractory (NR) species measured by the AMS are summed with soil and metals from PIXE, and BC from the aethalometer to include the refractory species not measured by the AMS ("AMS+Refractory") due to their negligible vapor pressure at $600^{\circ} \mathrm{C}$ (Canagaratna et al., 2007). Soil mass is estimated from the PIXE measurements by the method of Malm et al. (Malm et al., 1994; Salcedo et al., 2006). Metal concentrations in fine PM are estimated using averaged chemical compositions reported by Moffet et al. (2008b) for those with high concentrations (from highest to lowest cation concentration: $\mathrm{Zn}: \mathrm{ZnCl}_{2}, \mathrm{Zn}\left(\mathrm{NO}_{3}\right)_{2}$ and $\mathrm{ZnO} ; \mathrm{Pb}: \mathrm{PbCl}_{2}$ and $\mathrm{Pb}\left(\mathrm{NO}_{3}\right)_{2} ; \mathrm{Na}: \mathrm{NaCl}$ and $\left.\mathrm{NaNO}_{3} ; \mathrm{PO}_{4}\right)$ and the average soil factor for the metals with very small concentrations $(\mathrm{Cu}, \mathrm{Cr}, \mathrm{Hg}, \mathrm{Mg}, \mathrm{Mn}, \mathrm{Ni}, \mathrm{Sn}, \mathrm{V}$, and $\mathrm{W})$. PIXE data are summed for stages B and C $(0.07-1.15 \mu \mathrm{m})$ of the DRUM impactor used to collect these samples, including some particles beyond the $\mathrm{PM}_{1}$ cut. Similarly, the $\mathrm{BC}$ concentrations are approximately $\mathrm{PM}_{2.0}$ (Marley et al., 2009), resulting in an upper limit for their mass contribution as all other measurements are $\sim \mathrm{PM}_{1}$. The total fine PM measurements used for comparison include the Grimm 
OPC $\mathrm{PM}_{1}$, the mass estimated from the SMPS data, and the light scattering at $532 \mathrm{~nm}$ from the PAS and $530 \mathrm{~nm}$ from the nephelometer. Note that none of these measurements is a true $\mathrm{PM}_{1}$ mass measurement. The Grimm instrument is based on an optical particle counter, which does not detect particles below $\sim 300 \mathrm{~nm}$ in diameter nor use an aerodynamic size cut curve. It attempts to account for these effects by using corrections from gravimetric measurements. The apparent volume calculated from the SMPS number distributions is converted to mass (assuming sphericity) with a compositiondependent density estimated from the AMS+refractory measurements (Fig. S-2: http://www.atmos-chem-phys.net/9/ 6633/2009/acp-9-6633-2009-supplement.pdf) and only includes particles from $15-436 \mathrm{~nm} d_{m}$ (mobility diameter). Figure S-3 shows the time series, diurnal cycles, and scatter plots of the different measurements. The different measurements are highly correlated and have similar diurnal cycles. The SMPS peaks a few hours earlier in the day, possibly due to an overestimation of the volume from fractal soot particles in the rush hour and to particle growth in the afternoon increasing the fraction of the mass beyond its size range. The OPC $\mathrm{PM}_{1}$ data have a slightly later peak than the other measurements, likely due to a similar effect of particle growth increasing the fraction of particles above its minimum size range. In Fig. S-3, we show that the AMS CE of 0.5 estimated from the measured composition results in consistent comparisons with all other $\sim \mathrm{PM}_{1}$ measurements. The largest discrepancy is with the SMPS and is most likely due to the lower size cut of that instrument, as is mentioned above. Figure S-4 shows the comparison of the measured size distributions from the AMS and SMPS. To explore the possible causes of the observed differences, different CEs were applied sequentially for each organic PMF-AMS component and also the inorganic components. There was not a clear improvement in the comparison with the other colocated $\sim \mathrm{PM}_{1}$ measurements for the various perturbations of CE. The sum of speciated (AMS+Refractory) fine PM is similar to the OPC $\mathrm{PM}_{1}$ estimate and higher than the SMPS estimates. The difference between both $\mathrm{PM}_{1}$ datasets and the SMPS is likely due to the differences in the size cuts. Some of the scatter may also be due to the use of 6-h averages for the dust (a.k.a. soil) and metal concentrations for the speciated fine PM. Overall, this level of agreement is typical for previous studies (Takegawa et al., 2005; Zhang et al., 2005b; DeCarlo et al., 2008; Dunlea et al., 2008), and we conclude that the AMS and the other instruments discussed performed well during MILAGRO. Table S-1 and Fig. S-3(h) show the $R^{2}$ values between all the mentioned total fine PM measurements, indicating that the agreement between all instruments, not just the AMS, have similar levels of scatter, with slightly less when comparing two optical measurements, as would be expected. This comparison indicates that the limitations in accuracy and precision evidenced by these comparisons are distributed among the different instruments and not dominated by the AMS.
Figure 1 shows the time series of the different species, while Fig. 2 includes the average mass fractions, size distributions, and diurnal cycles of the different species. On average, the non-refractory species quantified with the AMS account for $80 \%$ of the fine PM mass, while the refractory species account for $20 \%$. Figure $1 \mathrm{a}$ and $\mathrm{f}$ shows the dominance of OA during the majority of the campaign, consistent with previous studies (Chow et al., 2002; Salcedo et al., 2006; DeCarlo et al., 2008). Most species have a clear diurnal cycle (Fig. 2d), with the exception of soil and a weak cycle for sulfate. The diurnal cycle of submicron nitrate is controlled by $\mathrm{HNO}_{3}$ production from $\mathrm{OH}+\mathrm{NO}_{2}$, gas-to-particle partitioning to form ammonium nitrate with abundant gasphase $\mathrm{NH}_{3}$, reaction of $\mathrm{HNO}_{3}$ with dust, and $\mathrm{HNO}_{3}$ dry deposition, which have been discussed in detail before for Mexico City (Salcedo et al., 2006; DeCarlo et al., 2008; Hennigan et al., 2008; Querol et al., 2008; Zheng et al., 2008; Fountoukis et al., 2009). The submicron nitrate increases during the latter part of the campaign, consistent with the decreased concentration of supermicron dust (Querol et al., 2008) due to precipitation during this period (Fast et al., 2007), resulting in reduced irreversible reactions of $\mathrm{HNO}_{3}$ with dust to form supermicron nitrates (Querol et al., 2008; Zheng et al., 2008; Fountoukis et al., 2009). Figure S-5 shows the increased precipitation and decreased coarse PM during this latter period that coincides with increased nitrate. Additionally, the slightly lower temperature and increased $\mathrm{RH}$ during this period may also favor the partitioning of $\mathrm{HNO}_{3}$ to fine aerosols, but are insufficient to explain the observed change.

Sulfate is present in a similar fraction to nitrate, yet with a much weaker diurnal cycle and a larger background, consistent with the non-volatile character of sulfate and the more regional character of this species in Mexico City and the Central Mexican Plateau (Salcedo et al., 2006; DeCarlo et al., 2008; Huffman et al., 2009a). The ammonium concentration follows those of nitrate and sulfate, as expected for nearly fully neutralized acids as described in previous studies (Salcedo et al., 2006; DeCarlo et al., 2008). Note that the pH of these aerosols when they are liquid will still be well below 7 (San Martini et al., 2006; Zhang et al., 2007b). The ammonium balance (Fig. S-6) determined from the high resolution ions is consistent with neutralized aerosols within the accuracy of this determination. It also shows a clear reduction in the scatter due to the reduction in $\mathrm{NH}_{4}^{+}$measurement noise, mainly due to the use of a ToF-AMS, compared to Fig. 10 of Salcedo et al. (2006) which used the interference-subtracted UMR ions from a quadrupole-AMS. The reduction in noise due to the use of the directly-measured $\mathrm{HR} \mathrm{NH}_{\mathrm{x}}^{+}$ions instead of the estimation of the same ions with the fragmentation table (Allan et al., 2004) is minor in this case, although it may be more important at lower $\mathrm{NH}_{4}^{+}$concentrations. In terms of the organic nitrates (ONs), at present we are only able to state that their contribution to total nitrate and total $\mathrm{OA}$ is minor based on the ammonium balance. If the AMS nitrate signal was dominated by ONs there would be a large "ammonium 


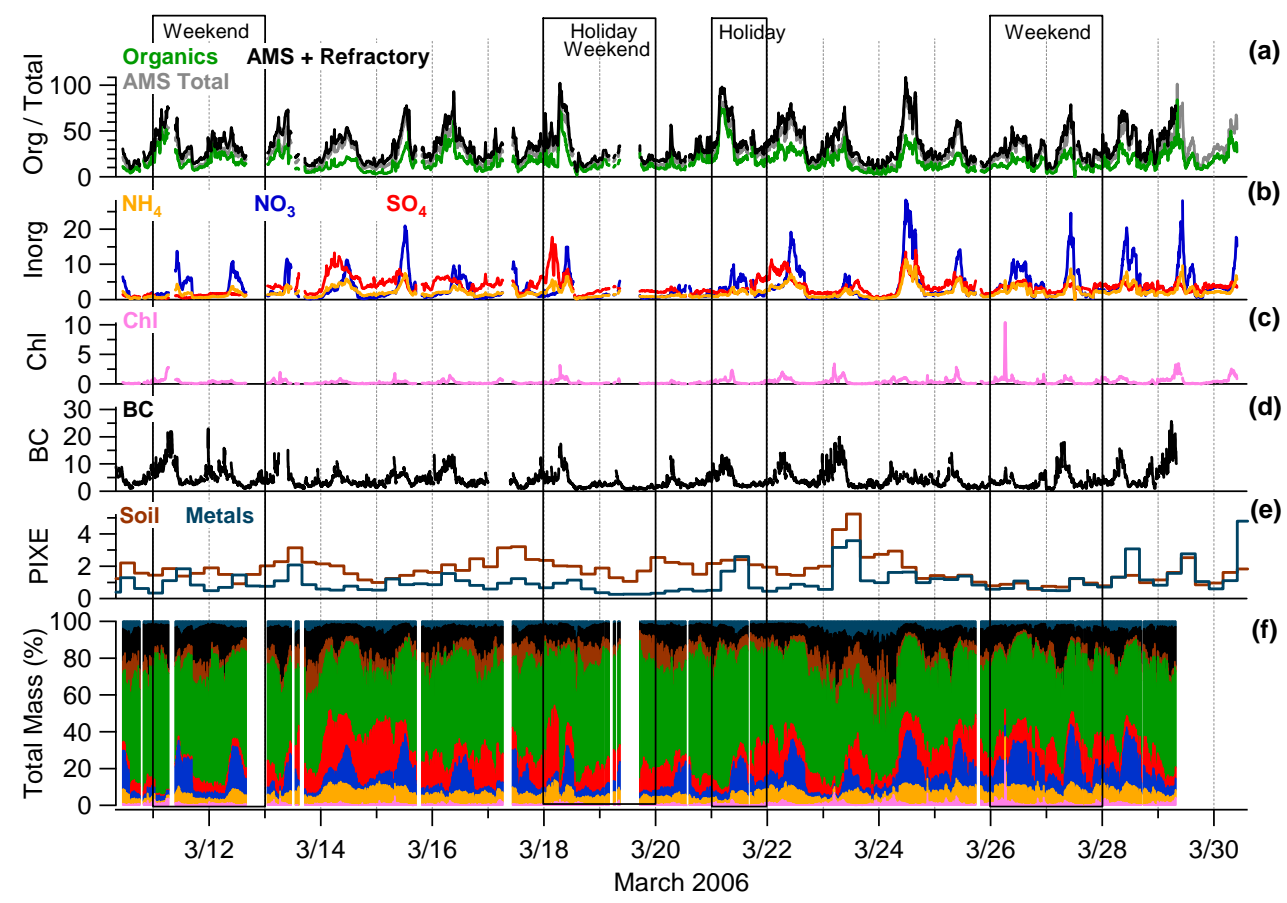

Fig. 1. Time series of mass concentrations as sampled by the AMS in $\mu \mathrm{g} \mathrm{am}^{-3}$ : (a) OA, AMS total, and AMS+refractory; (b) ammonium, nitrate, and sulfate; (c) chloride; (d) BC; (e) metals and soil. Panel (f) shows all species in the same colors the same as panels (a-e) as a percentage of the total mass (AMS+BC+metals+soil). Holidays and weekends are indicated with boxes.

(a)

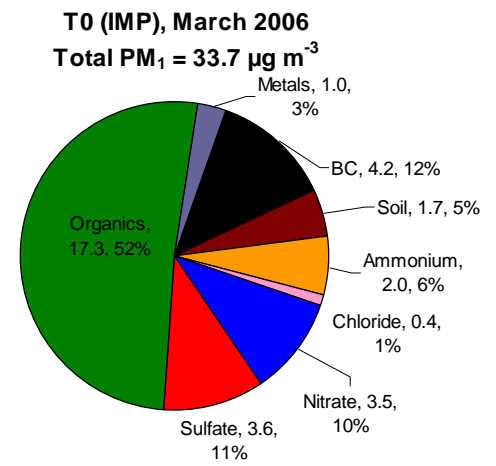

(c)

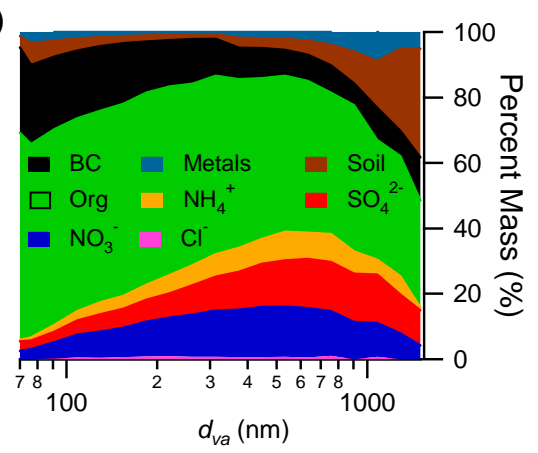

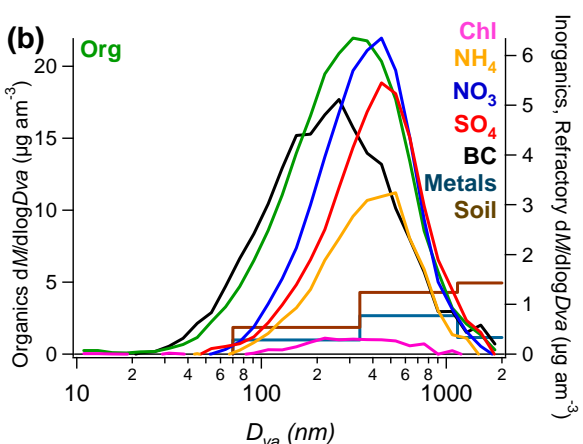

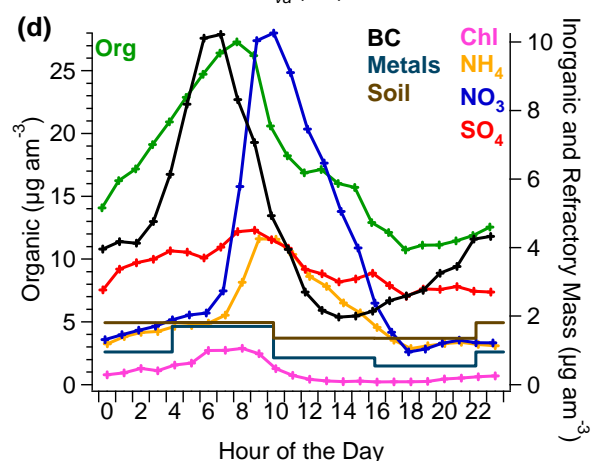

Fig. 2. $\mathrm{PM}_{1}$ aerosol mass concentrations, size distributions, and diurnal profiles. AMS species plus refractory species (a) average mass concentrations, (b) size distributions, (c) NR-PM 1 size distributions by percent mass, and (d) diurnal profiles. 
deficit" and large scatter when the ammonium balance analysis is performed assuming that all of the AMS nitrate signal is ammonium nitrate. Neither effect is observed in Fig. S-5, which indicates that ammonium nitrate is the dominant form of nitrate in Mexico City, consistent with the aircraft measurements (DeCarlo et al., 2008), PILS measurements at T1 (Hennigan et al., 2008), and previous studies (Salcedo et al., 2006). This is also consistent with Gilardoni et al. (2009), who report the contribution of ONs and organosulfates to be small based on FTIR measurements on MILAGRO samples at several sites. In Mexico City ONs should make a similar fractional contribution to submicron OA (when the mass of all OA molecules that have a nitrate group is summed) than to submicron nitrate. For example, if $5 \%$ of the nitrate signal was due to ONs and we assume a MW of $250 \mathrm{amu}$ for these species, the contribution of ONs to OA mass would be $4 \%$. Additional laboratory calibrations in the HR-ToF-AMS with organonitrate standards are needed before a detailed assessment of their contribution to ambient OA can be performed. Our group and several other groups in the AMS community are active in that area (Farmer et al., 2008).

Chloride is a very small $(\sim 1 \%)$ fraction of the fine PM observed at T0, as it was during MCMA-2003, but does not show the very numerous and large (up to $40 \mu \mathrm{g} \mathrm{am}^{-3}$ ) late night/early morning spikes of $\mathrm{NH}_{4} \mathrm{Cl}$ observed during that campaign (Salcedo et al., 2006). Thermal denuder analysis (Huffman et al., 2009a) suggests that approximately twothirds of the AMS chloride is due to $\mathrm{NH}_{4} \mathrm{Cl}$ or species of similarly high volatility, while the rest may be due to more refractory species such as $\mathrm{PbCl}_{2}$, which were identified with the ATOFMS (Moffet et al., 2008b). BC represents a significant fraction, $12 \%$ on average, of the aerosol and has a time series indicative of the interaction between primary emissions that peak during the morning traffic hours $(\sim 06: 00-$ 08:00 a.m. LST) and the boundary layer dilution peaking in the afternoon, as has been reported previously for the area (Salcedo et al., 2006; Marley et al., 2009). The soil fraction, $5 \%$, is similar to that determined during MCMA-2003 and may be due to both urban sources, e.g. dust re-suspension by vehicles, and non-urban sources. The metal concentration represents a small fraction of the fine PM mass with an average of $3 \%$. The range in species fractional composition of the fine PM does not show major deviations from the average composition shown in Fig. 2a. (Fig. S-7 shows histograms of the mass concentrations and the percent of the $\mathrm{PM}_{1}$ mass contributions for all species mentioned from the sampling period.) OA ranges from $20-80 \%$ of the fine PM mass with the NR inorganic species comprising 5-50\% of the PM mass and $\mathrm{BC}$ rarely exceeding $30 \%$ of the fine PM.

The campaign-average mass concentrations and fractional composition are compared with those from two previous campaigns (Chow et al., 2002; Salcedo et al., 2006) and aircraft data aloft over Mexico City during several afternoons during MILAGRO (DeCarlo et al., 2008) in Fig. S-8. (The locations of the three ground sites within the basin can be seen in Fig. S-1). All ground campaigns have similar fine PM mass concentrations and species fractions across the timeframe of the campaigns, 1997-2006. The data from 1997 have $\sim 15 \%$ more mass than the later studies, a larger refractory fraction, and a slightly lower OA fraction. The MCMA2003 data have both the largest OA mass concentration and fraction, likely due to the large impact of BB emissions from the Yucatan during the latter part of that campaign (Salcedo et al., 2006; Molina et al., 2007). However, it is not clear that any interannual trends can be derived from these comparisons due to the different locations and times of the measurements in addition to the short duration of all the campaigns. The aircraft data have less non-refractory mass (19 vs. $25 \mu \mathrm{g} \mathrm{am}^{-3}$ under T0 conditions) than measurements on the ground. The organic concentration measured by the aircraft in the afternoons is only $2 / 3$ of that observed on the ground as a 24-h average. The nitrate fraction is larger in the aircraft than at T0, likely because the flights were in the afternoon when nitrate is also higher at the ground compared to the 24-h average (Fig. 2) and also likely due to increased partitioning due to the lower temperatures and higher humidities aloft (Neuman et al., 2003; Morino et al., 2006). Species diurnal cycles from MILAGRO are compared with those from MCMA-2003 in Fig. S-9 and are overall similar. Average AMS mass spectra from the entire MCMA-2003 and 2006 campaigns (Fig. S-9) are also similar.

Species size distributions are shown in Fig. 2b. The BC size distribution was estimated from the signal at $m / z 57$ (corrected for the OOA signal fraction) and then normalized to the BC mass (Zhang et al., 2005c; Cubison et al., $2008 \mathrm{a})$. The distributions peak at $300-400 \mathrm{~nm}\left(d_{v a}\right)$, and below $100 \mathrm{~nm}$ they are overwhelmingly dominated by OA and $\mathrm{BC}$, presumably due to combustion emissions (Slowik et al., 2004). These distributions and mass fractions are very similar to the MCMA-2003 results (Salcedo et al., 2006) (Fig. S11). Figure $S-4$ shows a comparison of the size distribution from the speciated measurements with that from the SMPS. The increased mass detected by the AMS under $200 \mathrm{~nm} d_{v a}$ is likely due to different sizing of fractal particles between the two instruments (DeCarlo et al., 2004; Slowik et al., 2004).

\subsection{Investigating OA components/sources with Positive Matrix Factorization (PMF)}

Four OA components were identified from AMS spectra using PMF: chemically-reduced urban primary emissions (hydrocarbon-like OA, HOA), oxygenated OA (OOA, mostly a surrogate for secondary OA or SOA), biomass burning OA (BBOA), and a local primary nitrogen-containing source (local OA or LOA) with a hydrocarbon-like backbone and an atomic nitrogen-to-carbon ratio four times higher than for the other factors $(\mathrm{N} / \mathrm{C} \sim 0.06)$. Figure S-12 includes PMF diagnostic plots (Ulbrich et al., 2009). In this section we describe each component, identify tracer ions, and compare 
the component mass spectra (MS) and ambient ratios with components from previous campaigns and the component time series with tracer species from co-located measurements.

\subsubsection{Identification of PMF components using MS profiles and comparison with tracer time series}

PMF components are identified by their MS signatures and the correlation of their time series with tracers, and then confirmed with additional information such as diurnal cycles and ratios to tracers (Zhang et al., 2005c; Ulbrich et al., 2009). Figure 3 shows the mass spectral (MS) profiles of the four components identified by PMF for the entire campaign, which are similar to those reported in several previous studies (e.g. Zhang et al., 2005c; Lanz et al., 2007; Nemitz et al., 2008; Ulbrich et al., 2009). Figures 4 and 5 compare the time series of the mass concentrations of the four OA components with co-located measurements, while the time series and fractional mass composition of the four PMF factors are shown in Fig. S-13. The elemental compositions of these components are similar to those reported previously (Aiken et al., 2008). The average contribution of each PMFAMS component to the mass from each element in the OA $(\mathrm{C}, \mathrm{H}, \mathrm{O}, \mathrm{N})$ is shown in Fig. 6. On average, $61 \%$ of the OA mass is from carbon, $29 \%$ from oxygen, $9 \%$ from hydrogen, and $1 \%$ from nitrogen. Of the organic oxygen, $2 / 3$ of it is found within the OOA component, while $1 / 3$ of the organic nitrogen is within the LOA component. Compared with a PMF solution using only the UMR spectra, the increased information from the HR ions allows for a more direct separation of the components, especially of HOA and BBOA, as BBOA has some hydrocarbon-like structure in its UMR MS profile. The differences in the mass spectral signatures of HOA and BBOA are enhanced in high-resolution in comparison to unit mass resolution since BBOA has an increased oxygen-content (Aiken et al., 2008), as shown in Fig. 3 and with a scatter plot of the MS profiles in Fig. S-14, $\left(R^{2}=0.88\right.$ in UMR; 0.64 in HR).

The HOA mass spectrum is similar to that determined in Pittsburgh (Zhang et al., 2005a, c), as compared in Fig. S15. Its $\mathrm{O} / \mathrm{C}$ is $0.16 \pm 0.05$, which is higher than the values of 0.03-0.04 determined for motor vehicle exhaust and more similar to the $0.11-0.14$ determined for meat cooking aerosols and 0.08 for plastic burning, all of which have hydrocarbon-like mass spectra in UMR (Mohr et al., 2009). This may indicate that the HOA identified here contains some mass from other combustion-related urban sources such as food cooking and trash burning, and possibly also some lightly oxidized SOA formed from e.g. large alkanes (Kroll et al., 2007). Also, it is possible that the HOA still contains some residual BBOA that is not completely separated even in the HR analysis. An upper limit for this effect is that up to $15 \%$ of the HOA during the high fire periods may arise from BB sources (Aiken et al., 2009), with this interference being negligible during the low fire periods as is discussed in more detail in the companion paper. The HOA mass concentration shows a high correlation in time with $\mathrm{BC}\left(R^{2}=0.65\right)$ and $\mathrm{CO}(\mathrm{g})\left(R^{2}=0.57\right)$, which is consistent with the identification of HOA as being dominated by primary combustion sources and consistent with analyses from previous campaigns (e.g. Zhang et al., 2005c; Volkamer et al., 2006). Lastly, the average ratio of $\mathrm{HOA} / \mathrm{BC}$ is similar to previous US campaigns, while the ratio of $\mathrm{HOA} / \mathrm{CO}(\mathrm{g})$ is somewhat higher.

The OOA mass spectrum is also similar to what was found in Pittsburgh (Zhang et al., 2005a, c), compared in Fig. S-16. A recent study showed that the AMS mass spectra of several primary sources (meat-cooking, trash-burning, and vehicle emissions; Mohr et al., 2009) were very different from that of OOA and more similar to HOA (and to BBOA in the case of paper burning). OOA has been associated with SOA in multiple previous studies (Zhang et al., 2005a, c; Takegawa et al., 2006; Volkamer et al., 2006; Kondo et al., 2007; Herndon et al., 2008) and SOA is formed very efficiently from urban emissions in Mexico City (Volkamer et al., 2006; Kleinman et al., 2008; de Gouw et al., 2009). Therefore, the time series of OOA is compared with those of two secondary tracers, submicron particulate nitrate and $\mathrm{O}_{\mathrm{x}}$ $\left(\mathrm{NO}_{2}(\mathrm{~g})+\mathrm{O}_{3}(\mathrm{~g})\right) . \mathrm{O}_{3}$ has been shown to correlate with SOA production in Mexico City (Volkamer et al., 2006) and elsewhere (Zhang et al., 2005c), but $\mathrm{O}_{\mathrm{x}}$ is a better tracer of photochemical oxidant production because it eliminates the effect of the titration of $\mathrm{O}_{3}$ by fresh $\mathrm{NO}(\mathrm{g})$ emissions (Herndon et al., 2008). Particulate nitrate is formed due to photochemistry starting at sunrise and partially evaporates in the afternoons (Salcedo et al., 2006; Hennigan et al., 2008; Zheng et al., 2008). The correlation of OOA with particulate nitrate $\left(R^{2}=0.71\right.$, Fig. $\left.5 \mathrm{c}\right)$ is slightly better than with $\mathrm{O}_{\mathrm{x}}\left(R^{2}=0.55\right.$, Fig. 5d), yet both show very similar temporal changes with OOA in the time series comparison (Fig. 4b). This correlation is especially clear during periods with low background concentrations, such as 24 March which follows a cold surge event that brought clean air to the Mexico City area, similar to a case study from MCMA-2003 which has been studied in some detail (Volkamer et al., 2006, 2007; Dzepina et al., 2009). The observed ratio of $O O A / O_{x}$ is similar to that determined by Herndon et al. (2008) at the Pico Tres Padres site above Mexico City for periods dominated by SOA production for less-aged airmasses, consistent with the relative locations of the two sites (Fig. 5d). All of these pieces of evidence strongly suggest that OOA is dominated by SOA. A fraction of the background OOA, of the order of $1-15 \mu \mathrm{g} \mathrm{am}^{-3}$ is due to regional biogenic SOA formed over the coastal ranges and advected over the Central Mexican Plateau, according to both 3-D modeling and tracer-derived estimates (Hodzic et al., 2009). Some of the SOA may be formed from BB emissions (Grieshop et al., 2009), although field studies report a wide variation of the relative importance of net BB SOA formation from negligible to comparable to the BB POA (Capes et al., 2008; Cubison et al., 2008b; Yokelson et al., 2009). For this 


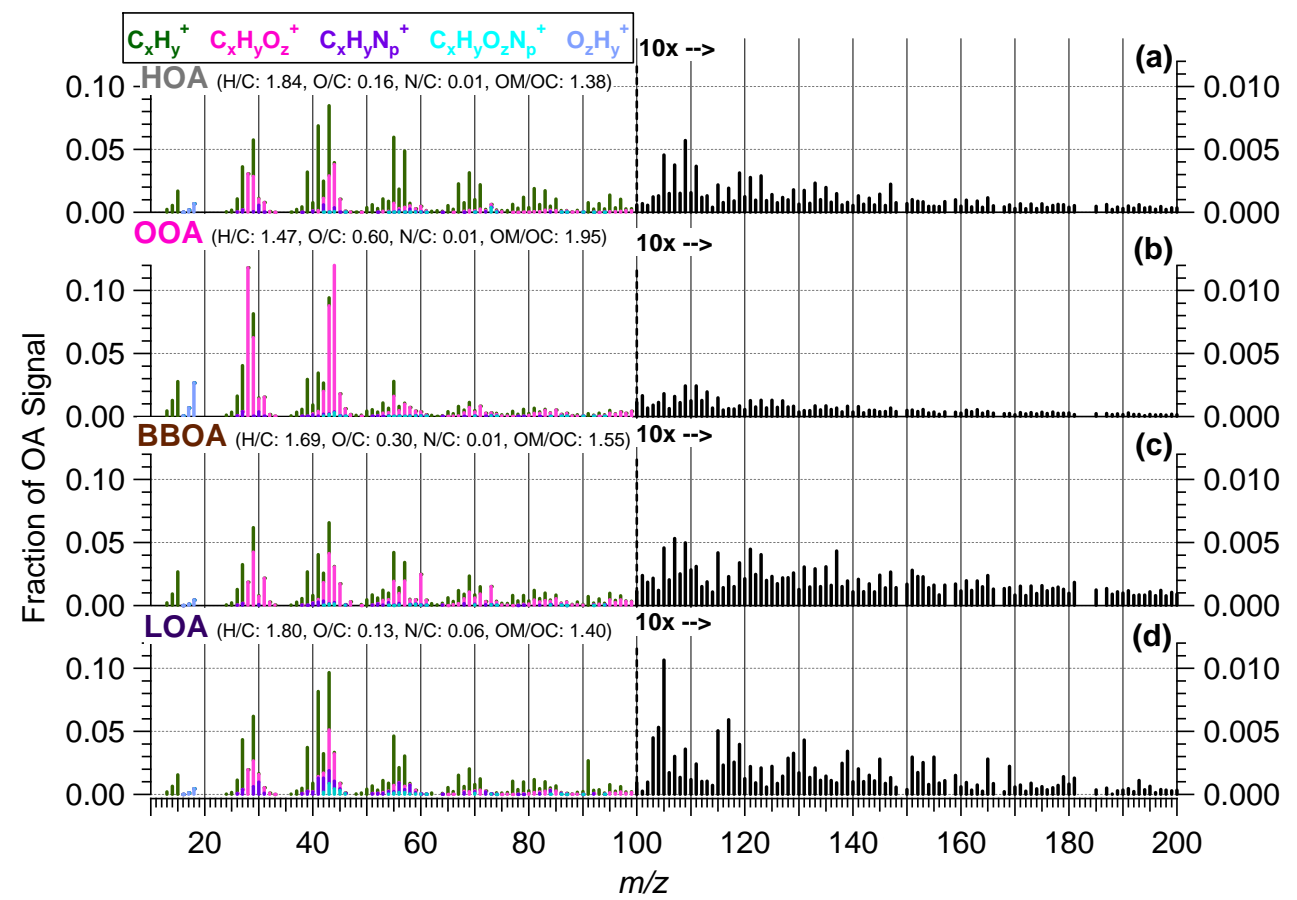

Fig. 3. Mass spectra of four PMF-AMS components with calculated atomic ratios. HR mass spectra under $m / z 100$ and UMR signals above $m / z, 100$. HR signals are colored by ion type.

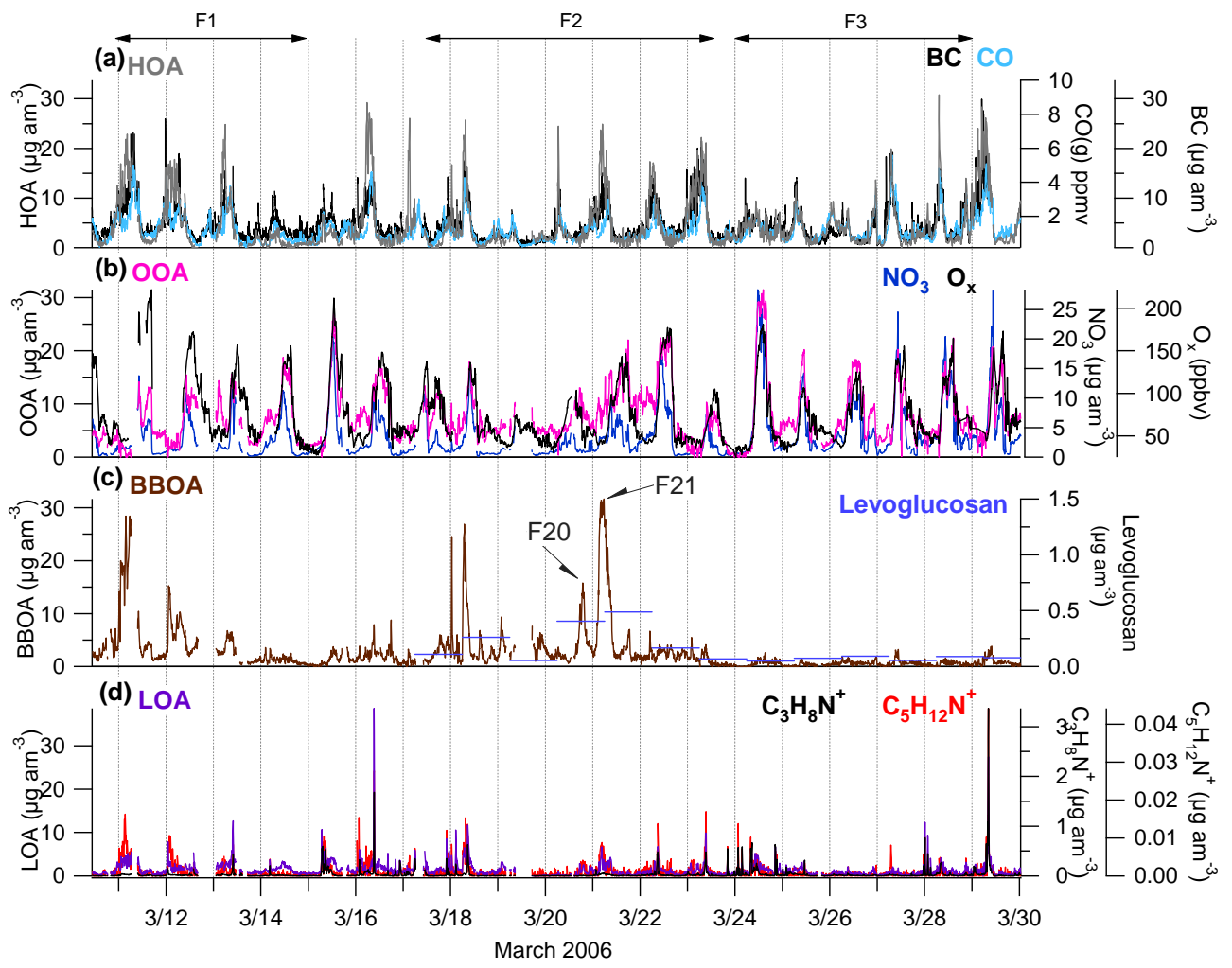

Fig. 4. Time series of PMF-AMS sources and corresponding tracers. Time series of (a) $\mathrm{HOA}, \mathrm{BC}$, and $\mathrm{CO}$, (b) $\mathrm{OOA}, \mathrm{NO}_{3}$, and $\mathrm{O}_{\mathrm{x}}$, (c) BBOA, levoglucosan, and (d) LOA, $\mathrm{C}_{3} \mathrm{H}_{8} \mathrm{~N}^{+}, \mathrm{C}_{5} \mathrm{H}_{12} \mathrm{~N}^{+}$. Periods (F1, F2, F3) are indicated for reference to the fire impact period analysis in Part 2 (Aiken et al., 2009). 

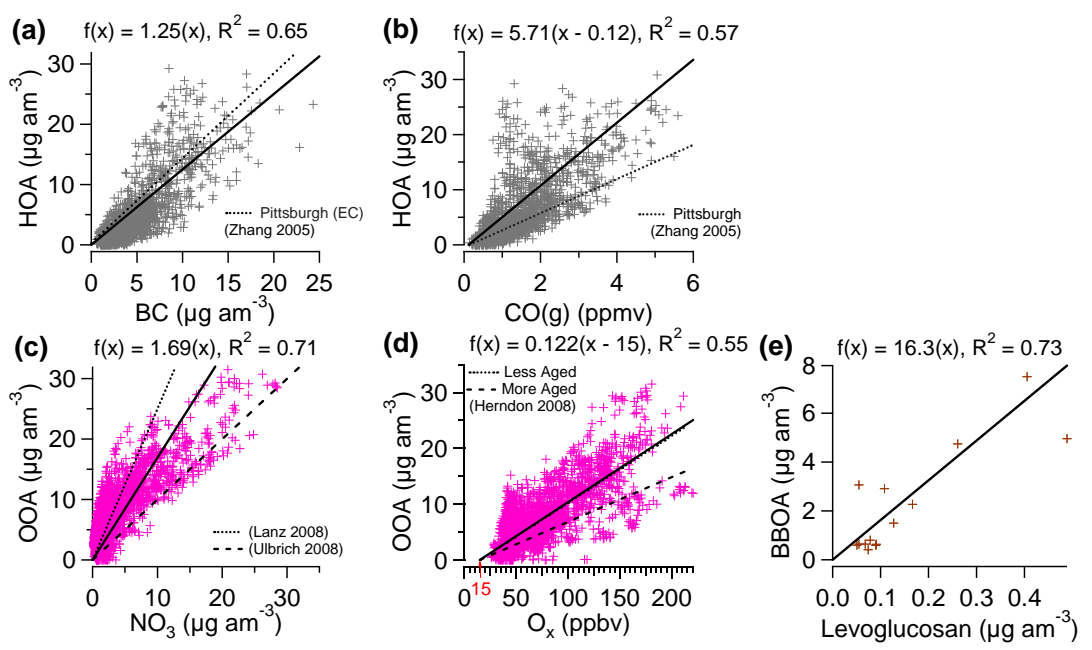

Fig. 5. Scatter plots with linear regressions and $R^{2}$ values for (a) $\mathrm{HOA}$ vs. BC, (b) $\mathrm{HOA}$ and $\mathrm{CO}(\mathrm{g}),(\mathbf{c}) \mathrm{OOA}_{\text {and }} \mathrm{NO}_{3}$, (d) $\mathrm{OOA}_{\mathrm{As}} \mathrm{O}_{\mathrm{x}}$, and (e) BBOA vs. Levoglucosan. Scatter plots include linear regressions determined at other locations in (a, b, d) for comparison. The OOA vs. $\mathrm{O}_{\mathrm{x}}$ scatter plot is fitted with an intercept of $15 \mathrm{ppb} \mathrm{O}_{\mathrm{x}}$ for $\mathrm{OOA}=0$, consistent with the results of Herndon et al. (2008).

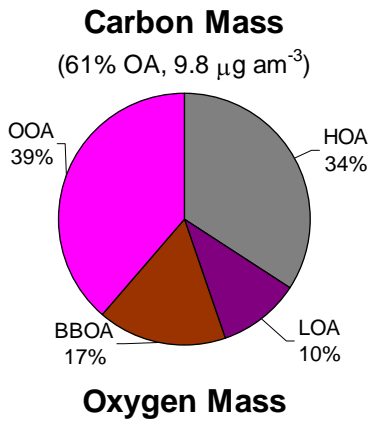

$\left(29 \%\right.$ OA, $\left.4.6 \mu \mathrm{g} \mathrm{am}^{-3}\right)$

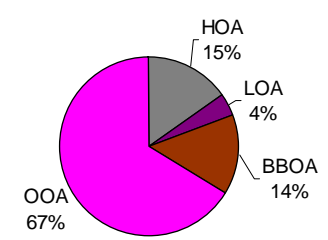

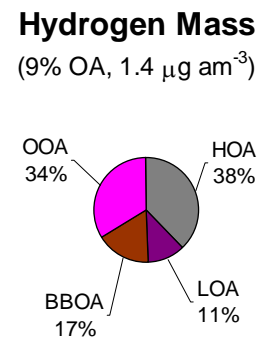

\section{Nitrogen Mass}

$\left(1 \% \mathrm{OA}, 0.2 \mu \mathrm{g} \mathrm{am}^{-3}\right)$

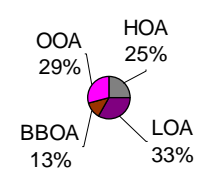

Fig. 6. Average elemental mass of carbon, hydrogen, oxygen, and nitrogen from the whole campaign. Each elemental signal is divided into the percent contribution from the four PMF-AMS components. The relative size of the circles is proportional to the mass concentration of each element.

dataset, several pieces of evidence such as the low levels of the $\mathrm{BB}$ tracer acetonitrile during the afternoons when OOA is highest (Fig. 10), and a lack of change of OOA levels between high and low fire periods (Aiken et al., 2009) suggests that the contribution of SOA arising from BB emissions to total OOA at T0 is not major, with the exception of one period described below. This may be due to the fact that the higher BBOA impacts are observed in the early morning (see below), often from plumes emitted from fires burning during the evening and night, and for which photochemistry has not yet acted on the emissions (Aiken et al., 2009).

The background level of OOA at night averages $4.6 \mu \mathrm{g} \mathrm{am}^{-3}$ during the campaign (defined as the average from 08:00 p.m.-04:00 a.m.), part of which is likely due to some carryover from the previous day, which would be expected to be higher for OOA than particulate nitrate due to the much lower volatility of OOA, resulting in less evaporation (Huffman et al., 2009a). Some of the background OOA is also likely due to regional more aged aerosol from pollution, biomass burning, and biogenic SOA sources. This OOA background does not show major variation across periods of higher and lower BBOA impact (Aiken et al., 2009). One exception occurs during the nights of 20 and 21 March, which follows a period of intense fire impact and has a higher OOA concentration, probably due to SOA formed from BB emissions. Further evidence of this SOA is described in the paper by Stone et al. (2008) where elevated pinonic acid and maximum OC fractions from SOA sources were found in the samples collected during the night of 21 March and the following day. Pinonic acid has been identified in the SOA produced from the photochemical oxidation of $\alpha$-pinene in chamber studies (Yu et al., 1999). $\alpha$-pinene is emitted during pine burning (Grieshop et al., 2009), and the correlations in Stone et al. (2008) support the hypothesis that the increased OOA during this period is due to SOA formed from biomass burning emissions.

The BBOA mass spectrum, which is well constrained due to periods of large BB impact at $\mathrm{T} 0$, is similar to a source spectrum from a combination of smoldering and flaming pine burning OA (Aiken et al., 2008) as shown in Fig. 7. It is also very similar to the spectrum of paper burning (Mohr et al., 2009) and to spectra from refuse burning sampled at a rural site near Mexico City during MCMA-2003 (not shown; T. Onasch, personal communication, 2009). The BBOA time series is compared with levoglucosan measurements from 

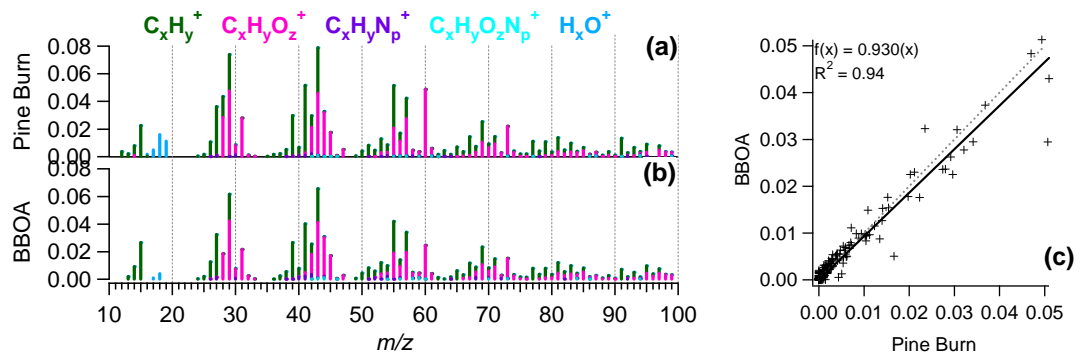

Fig. 7. High resolution mass spectra from (a) primary pine burning emissions and (b) Mexico City BBOA with a (c) scatter plot and linear regression of the high resolution mass spectra. Mass spectral signals are colored by ion type.
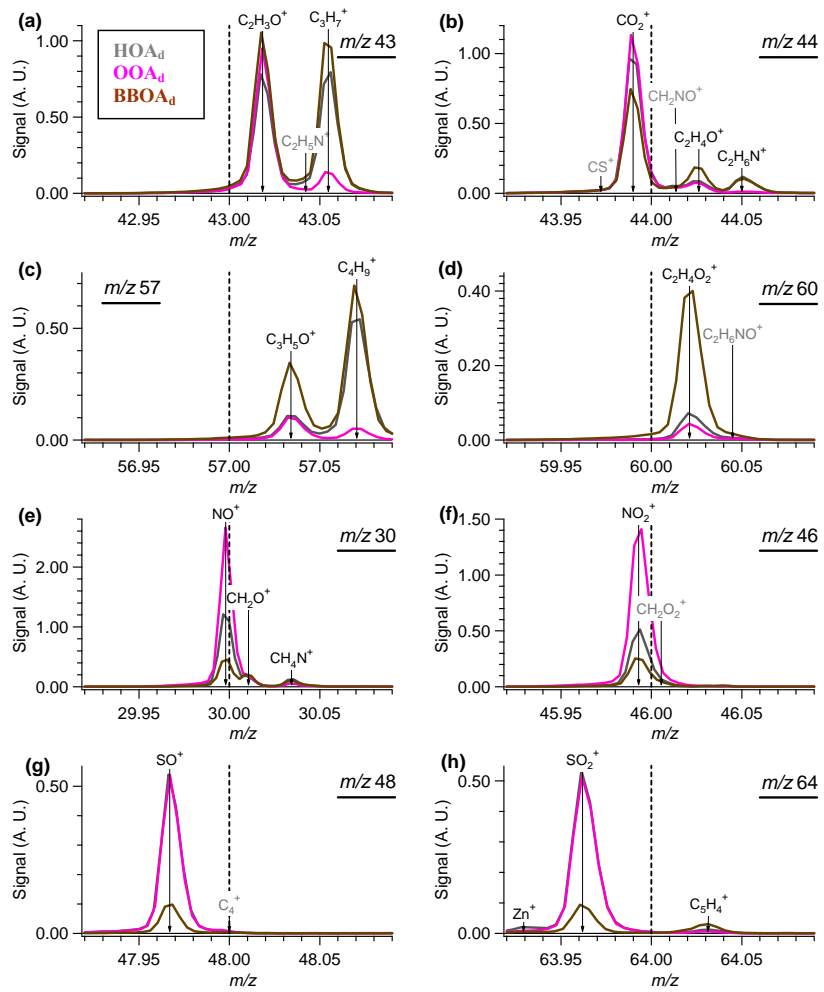

Fig. 8. High resolution ion signals for important (a-d) Organic and (e-h) Inorganic fragment ions. Signals are averaged over $\sim 5 \mathrm{~h}$ periods when one PMF factor dominates total OA (e.g. $\mathrm{HOA}_{d}=\mathrm{HOA}-$ dominated). (Grey ions are included for reference, but not likely large contributions to the signals.)

GC-MS analysis (Figs. 4c and 5e, Stone et al., 2008). BBOA was averaged onto the filter timescales resulting in an $R^{2}$ of 0.73 . The slope of the regression indicates that levoglucosan is present at $6.1 \%$ of the BBOA mass detected by the PMF-AMS, which falls within the range of previous studies. Sullivan et al. (2008) reports an average mass percentage of $7.0( \pm 3.8) \%$ for levoglucosan/OC from different biomasses, equivalent to $\sim 4.4( \pm 2.4) \%$ of the $\mathrm{OM}$, using a conversion value of $1.6 \mathrm{OM} / \mathrm{OC}$, which encompasses the value determined here.
Additionally, the AMS signal at UMR $m / z 60$ has been used previously as a tracer for BBOA (e.g. Alfarra et al., 2007) and can be used to derive a levoglucosan-equivalent concentration from AMS measurements. First, $m / z 60$ is almost completely $\mathrm{C}_{2} \mathrm{H}_{4} \mathrm{O}_{2}^{+}$, as shown in Fig. 8d, consistent with a recent AMS analysis of multiple POA sources (Mohr et al., 2009 ), and is formed at $\sim 13 \%$ of the total signal for levoglucosan standards in the AMS (Aiken et al., 2007). It has been shown to be a clear marker ion for BBOA that is elevated during periods of high smoke impact (Alfarra et al., 2007) and persists despite some reduction with aging in BB plumes measured thousands of $\mathrm{km}$ away from the fire locations (Cubison et al., 2008b). This ion is also produced in smaller amounts from some other sources (such as carboxylic acids from SOA formation and also meat cooking; Mohr et al., 2009), and urban areas typically have a level of $\mathrm{m} / \mathrm{z}, 60 / \mathrm{OA}$ of $\sim 0.3 \%$ in the absence of biomass burning impacts (DeCarlo et al., 2008; Docherty et al., 2008; Ulbrich et al., 2009). We refer to the signal at $m / z 60$ after subtraction of $0.3 \%$ of the OA as "excess $m / z 60$ ", and define the "levoglucosan-equivalent" ("levog.-eq.") concentration as the concentration of levoglucosan that would be needed to produce the observed level of excess $m / z 60$. Figure 9 shows the comparison of levoglucosan from filter-GC/MS measurements (Stone et al., 2008) with the AMS levog.-eq. mass concentrations. The two quantities have an $R^{2}$ correlation of 0.79 , with the levog.-eq. mass being $\sim 3.2$ times that of levoglucosan. Sullivan et al. (2008) identified other carbohydrate anhydrides similar to levoglucosan such as mannosan and galactosan in woodsmoke WSOC for multiple fuel types. Although AMS mass spectra of these species are not available to our knowledge, it is expected that such species also produce $m / z 60$ in the AMS as they do in other electron ionization instruments, resulting in an "excess $\mathrm{m} / \mathrm{z} 60$ " signal. Therefore, "excess $m / z 60$ " in the AMS is still a good primary BBOA tracer, but represents a mass that exceeds that of levoglucosan alone. The regression between the AMS levog.eq. mass and BBOA has a $R^{2}$ of 0.93 with a ratio of 0.24 for levog.-eq. mass/BBOA mass, which could potentially be used to approximate BBOA in the absence of PMF-AMS. 


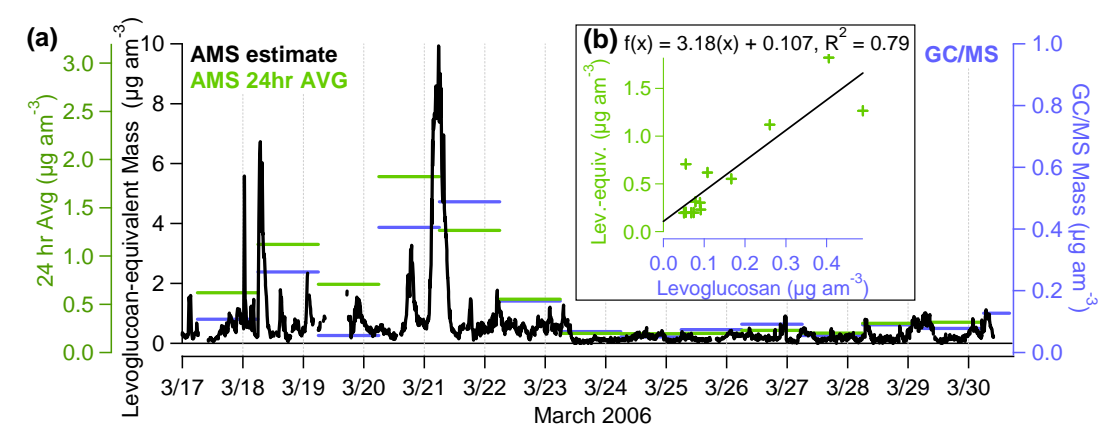

Fig. 9. Mass concentration of levoglucosan-equivalent compounds (a) as sampled with the AMS, including averages onto the same time scale as the levoglucosan measured by GC/MS (Stone et al., 2008), and (b) a scatter plot with linear regression of the comparison.

Figure $4 \mathrm{~d}$ shows the time series of the LOA mass concentration along with two nitrogen-containing ions $\left(\mathrm{C}_{3} \mathrm{H}_{8} \mathrm{~N}^{+}\right.$ at $m / z 58$ and $\mathrm{C}_{5} \mathrm{H}_{12} \mathrm{~N}^{+}$at $m / z 86$ ), which are often large peaks in aliphatic amine spectra (McLafferty and Turecek, 1993), showing that their spiky signals are correlated in time. The highly variable time series (Fig. 4d) and a diurnal cycle enhanced in the morning (Fig. 10b) strongly suggest a primary origin for this source. Further support is provided by the lower autocorrelation values for LOA (compared to other components: PMF-AMS factors, AMS inorganics, gasphase species) shown in Fig. S-17, which indicates a smaller spatial/temporal extent for this aerosol. Additionally, the LOA time series correlates with the co-located ATOFMS nitrogen-containing organic carbon (NOC) particle type that was "hypothesized to be amines from local industrial emissions based on the time series profile and back trajectory analysis" (Moffet et al., 2008a). Beyond the unusually high nitrogen fraction for the LOA component, of note are the high signals at $m / z$ 's $91\left(\mathrm{C}_{7} \mathrm{H}_{7}^{+}\right)$and 105 that distinguish its mass spectral profile from the more common primary component, HOA. The LOA component also comprises a high fraction of the OA ( 20\%) on the night of 23 March and the early morning of 24 March (Fig. S-13e) when the ATOFMS PbZn number count is high and is low during the weekend period of 26 March, where the ATOFMS also reports low concentration of these industrial particles. The source of LOA may or may not be the same as the PbZn source identified by the ATOFMS, and their correlation may reflect instead industrial emissions from the same localized area. Note that the LOA time series does not correlate with AMS NR chloride $\left(R^{2}=0.09\right)$.

The average mass fraction of the PMF OA components is shown in Fig. 10a, which is almost half (46\%) OOA and a third (29\%) HOA. The diurnal profiles in Fig. 10b point to the formation of OOA/SOA due to photochemistry beginning as early as 07:00-08:00 a.m. and peaking from 09:00 a.m.03:00 p.m. at $\sim 12.7 \mu \mathrm{g} \mathrm{am}^{-3}$. HOA shows a peak in the morning consistent with the rush hour and the effects of the low boundary layer height in the morning. BBOA and acetonitrile have similar diurnal profiles (Fig. 10c) which are
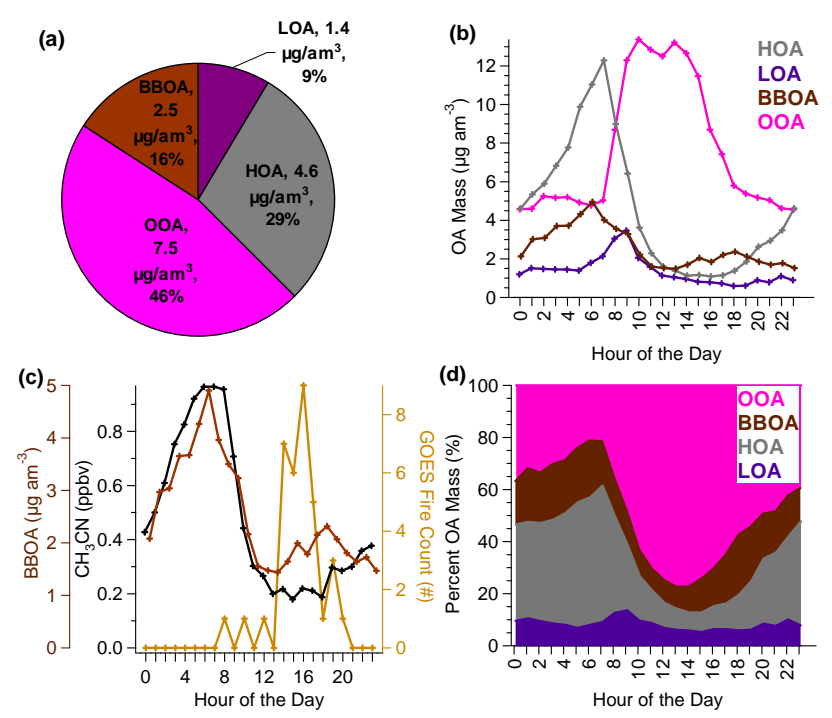

Fig. 10. PMF source (a) mass contributions to $\sim \mathrm{PM}_{1} \mathrm{OA}$, (b) diurnal profiles, (c) BBOA diurnal profile compared with that of acetonitrile and GOES fire counts, and (d) diurnal profiles by percent mass.

similar to the rush hour profile but with an earlier start, as was also observed at the $\mathrm{T} 1$ site for $\mathrm{CH}_{3} \mathrm{CN}$ (de Gouw et al., 2009). There is a second weaker peak in the BBOA diurnal cycle (reaching $2.3 \mu \mathrm{g} \mathrm{am}^{-3}$ at 06:00 p.m.) in the afternoon to early evening that follows the afternoon peak in fire counts from 02:00-09:00 p.m. as detected by the GOES satellite (http://www.goes.noaa.gov/) using FLAMBE (http://www.nrlmry.navy.mil/flambe/index.html), also shown in Fig. 10c. Figure 10d shows the diurnal cycle for the four components as a fraction of the total OA, indicating that the HOA mass is $\sim 35 \%$ during the night and begins to rise at 4 a.m. until 08:00 a.m., when it reaches its fractional peak at $52 \%$ of the OA. The OOA mass is $\geq 70 \%$ of the OA from 11:00 a.m. to 05:00 p.m., when SOA production would be expected to peak and when acetonitrile is lowest. BBOA comprises $16 \%$ of OA (diurnal range: $8 \%-23 \%$ ) on average. 


\subsubsection{High resolution ion signals - organic and inorganic}

The increased mass spectral information content obtained with the HR-ToF-AMS allows for improved separation of OA factors with PMF and increased chemical information of the total and factor OA, e.g. atomic ratios (Aiken et al., 2007, 2008) and ion families (Fig. 3), due to the increased mass resolving power (DeCarlo et al., 2006). Since this is one of the first reports of urban aerosol analysis using the HRToF-AMS, the contributions of different ions to some key $\mathrm{m} / \mathrm{z}$ 's of the AMS (which are often used as tracers in AMS studies) are shown in Fig. 8 for periods during the campaign when the OA was dominated by one of the three main PMF sources: HOA (which was $62 \%$ of the OA during the selected high-HOA period), OOA (87\% during the high-OOA period), BBOA (52\% during the high-BBOA period). Signals are in arbitrary units, but all have been scaled to the same air signal at $m / z 28\left(\mathrm{~N}_{2}^{+}=100\right.$, height). Similar data has been presented previously for aircraft measurements and source profiles (Dunlea et al., 2008; Mohr et al., 2009) and further information on characteristic ions and their contributions to different OA types is discussed by Mohr et al. (2009) and Huffman et al. (2009a) (Fig. S-18 includes all $\mathrm{m} / \mathrm{z}^{\prime}$ 's from 10-100 during the same periods as a reference for this and future studies). As expected, reduced ions such as $\mathrm{C}_{3} \mathrm{H}_{7}^{+}$ $(\mathrm{m} / \mathrm{z}, 43)$ and $\mathrm{C}_{4} \mathrm{H}_{9}^{+}(\mathrm{m} / \mathrm{z}, 57)$ are higher during periods dominated by $\mathrm{HOA}$ while $\mathrm{C}_{2} \mathrm{H}_{3} \mathrm{O}^{+}(\mathrm{m} / \mathrm{z}, 43)$ and $\mathrm{CO}_{2}^{+}(\mathrm{m} / \mathrm{z} 44)$ are higher during OOA-dominated periods. Both types of ions, and also especially $\mathrm{C}_{2} \mathrm{H}_{4} \mathrm{O}_{2}^{+}(m / z 60)$, are high during BBOA-dominated periods. The BBOA marker ion at $m / z 60$ is an unusual case in which the UMR signal is dominated by a single HR ion, which would allow the correlations discussed above (based on $\mathrm{m} / \mathrm{z}, 60$ ) to be conducted for UMR data without adding increased uncertainty. $\mathrm{CO}_{2}^{+}$dominates the signal within $m / z 44$, most markedly during high OOA periods, with the largest fraction of non- $\mathrm{CO}_{2}^{+}$signal occurring during high BBOA periods, consistent with source observations (Mohr et al., 2009). When comparing the main organic ions from the factor-dominated periods (Fig. 8) to the factor mass spectra (Fig. 3) some differences are apparent, such as the high-HOA period has an enhanced fraction of $\mathrm{C}_{2} \mathrm{H}_{3} \mathrm{O}^{+}(\mathrm{m} / z 43)$ due to the presence of $25 \%$ OOA during that period. The main inorganic fragment ions from nitrate and sulfate dominate the UMR signal at their respective $m / z$ 's almost completely when they are present (Fig. 8e-h and Fig. S-18). The main exceptions are the organic ions at $m / z 30\left(\mathrm{CH}_{2} \mathrm{O}^{+}\right.$and $\left.\mathrm{CH}_{4} \mathrm{~N}^{+}\right)$ that occur in both the HOA and BBOA-dominated periods, and $\mathrm{C}_{5} \mathrm{H}_{4}^{+}$at $m / 264$ during the BBOA-dominated periods. Additionally, the chloride ions at $\mathrm{m} / z 35$ and 36 dominate their respective UMR signals, while they do not at $\mathrm{m} / \mathrm{z} 37$ and 38 , consistent with the assumptions in the AMS UMR fragmentation table (Allan et al., 2004).

\subsubsection{Observed ratio of $\mathrm{OA}$ to excess gas-phase carbon monoxide}

The total OA/ $\Delta \mathrm{CO}$, where $\Delta \mathrm{CO}$ is the gas-phase $\mathrm{CO}$ measurement minus a regional boundary layer background of $\sim 120 \mathrm{ppb}$ (Herndon et al., 2008), has been reported during multiple campaigns, e.g. (de Gouw et al., 2005, 2009; Kleinman et al., 2008; de Gouw and Jimenez, 2009). The ratio can yield information about the sources and secondary formation of OA in urban airmasses since POA/ $\triangle \mathrm{CO}$ is low for urban emissions ( $\sim 5 \mu \mathrm{g} \mathrm{sm}^{-3} \mathrm{ppb}-1$, Zhang et al., 2005c) and the ratio increases greatly with SOA formation, e.g. de Gouw et al. (2009). Biomass burning can often have high $\mathrm{POA} / \Delta \mathrm{CO}$ ratios, reaching $200 \mu \mathrm{g} \mathrm{sm}^{-3} \mathrm{ppb}^{-1}$ (Knighton et al., 2007; DeCarlo et al., 2008; Yokelson et al., 2009), although mid and low ratios have also been reported for some biomasses (Sinha et al., 2004; Knighton et al., 2007). Thus, when urban and biomass emissions mix, the interpretation of $\mathrm{OA} / \Delta \mathrm{CO}$ data is very complex. To document the variation observed here and to allow comparison with other sites and studies, Fig. 11 shows $\mathrm{OA} / \Delta \mathrm{CO}$ observed at $\mathrm{T} 0$ along with ratios from previous studies. The $\mathrm{T} 0$ data are bounded at the lower end by the low primary emissions ratio for urban HOA (Zhang et al., 2005c; Docherty et al., 2008; this study). The points near the $\mathrm{HOA} / \triangle \mathrm{CO}$ lines are thus likely dominated by urban POA emissions. At the upper end the T0 data are bounded by values observed in both aged urban airmasses dominated by SOA (Volkamer et al., 2006; de Gouw et al., 2009; Kleinman et al., 2008; Dzepina et al., 2009) and forest fire emissions near Mexico City (Yokelson et al., 2007; DeCarlo et al., 2008). T0 is an urban setting and is heavily impacted by HOA emissions, but the dominant presence of higher $\mathrm{OA} / \triangle \mathrm{CO}$ ratios indicates important impacts from SOA formation and/or biomass burning sources. However, since both SOA formation and forest fire emissions can produce the higher $\mathrm{OA} / \triangle \mathrm{CO}$ ratios, their relative contributions cannot be separated with the $\mathrm{OA} / \Delta \mathrm{CO}$ analysis alone. This contrasts with the use of the $\mathrm{OA} / \Delta \mathrm{CO}$ technique in areas where only POA and SOA from urban pollution are thought to be making a major contribution, as under those circumstances the SOA contribution can be estimated with the "COtracer method" alone, which estimates POA as the measured $\triangle \mathrm{CO}$ multiplied by the primary $\mathrm{POA} / \triangle \mathrm{CO}$ ratio, and assigns the rest of the measured OA to SOA (Takegawa et al., 2006; Docherty et al., 2008). Similarly, the contribution of forest fires cannot be reliably estimated in our case with a similar method, since the urban $\mathrm{OA} / \triangle \mathrm{CO}$ is not well-characterized and varies with photochemical age due to SOA formation.

\subsection{Comparison of OA apportionment from PMF-AMS and CMB-OMM}

PMF-AMS and CMB-OMM results have been compared once previously, and they produced similar results for the fraction of SOA/OA during the summer in Riverside, CA, 


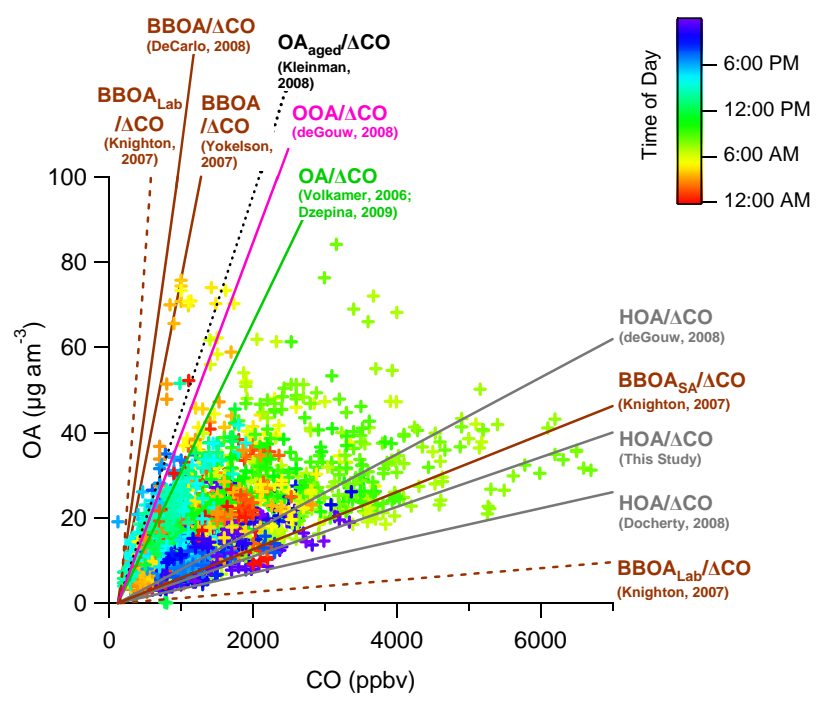

Fig. 11. Scatter plot of AMS Organic Mass (OA) vs. CO(g) for the entire campaign at $\mathrm{T} 0$, showing the wide variation in this ratio. Slopes derived from the literature and from this study are also shown (see text). The highest and lowest slopes in the literature are from the study of Knighton et al. (2007) who sampled laboratory BBOA from many different biomasses, the slopes shown are the extremes of their dataset. The $\mathrm{BBOA}_{S A} / \triangle \mathrm{CO}$ ratio is that sampled by Knighton et al. (2007) for a fire detected at the Santa Ana peripheral site during MILAGRO.

although, with a less pronounced diurnal cycle in CMBOMM than PMF-AMS (Docherty et al., 2008). CMB-OMM sources are derived as organic carbon mass (OC), which does not include other elements in the organic species such as $\mathrm{O}$, $\mathrm{H}, \mathrm{N}$, while PMF-AMS results do include those elements in their OA mass. For comparison, CMB-OMM sources were converted from $\mathrm{OC}$ to $\mathrm{OA}$ using $\mathrm{OM} / \mathrm{OC}$ values based on Aiken et al. (2008) (Vegetative Detritus and Woodsmoke, 1.60; Vehicle, 1.20), which are consistent with other methods and the PMF sources found here. The "Other" category of CMB-OMM is calculated here as the difference between the AMS OA measurement and the OA apportioned to primary sources with CMB-OMM to minimize noise in the comparison. The primary CMB-OMM sources were apportioned from $\mathrm{PM}_{2.5}$ filters, which could produce a small positive bias in these sources and a negative one in the secondary sources in comparison to the PMF-AMS components. However, the mass concentration between $\mathrm{PM}_{1}$ and $\mathrm{PM}_{2.5}$ is small (Fig. S-5d) and has an increased fraction of dust and a reduced fraction of OA (Fig. 2c) so this bias is expected to be small.

A comparison of the daily average OA apportionment of the two methods and the average composition from the period with overlapping measurements is shown in Fig. 12ab. Figure $12 \mathrm{c}-\mathrm{d}$ compares the relative mass fractions for the overlapping sampling period. Most of the components found by both methods are similar and have similar magnitudes: HOA/Vehicle, BBOA/Woodsmoke, and OOA/Other.
As discussed above, the PMF-AMS OOA is thought to be dominated by SOA, while Stone et al. (2008) associates the "Other" CMB-OMM component with SOA based on its correlation with WSOC at the near-urban site during MILAGRO (T1, Fig. S-1). The component mass fractions from both methods show similar patterns, e.g. with high BBOA/Woodsmoke on 18, 20, 21 and 22 March and low BBOA/Woodsmoke on most other days during the overlapping period. One difference is that CMB-OMM resolves a small vegetative detritus source $(\sim 2 \%)$ while PMF-AMS resolves a LOA component $(9 \%)$ which appears to be more tied to industrial emissions as discussed earlier. It is not surprising that PMF-AMS cannot resolve a source which accounts for only $2 \%$ of the mass based on previous method characterization (Ulbrich et al., 2009) and which, since it is likely formed by mechanical processes, may be present mostly in the $\mathrm{PM}_{2.5}-\mathrm{PM}_{1}$ size range that the AMS does not sample. Similarly, CMB-OMM cannot retrieve the local LOA primary source since a source profile for it was not available. LOA will likely be lumped as "Other" in CMB. If the average LOA fraction (9\%) is subtracted from the "Other" CMBOMM fraction (58\%), we obtain a better estimate of SOA fraction from CMB-OMM (49\%) which improves the comparison with the PMF-AMS OOA (46\%).

Figure 13 shows scatter plots between the three main components from each method, as well as a hybrid plot showing CMB-OMM Other minus PMF-AMS LOA vs. PMFAMS OOA to account for the likely attribution of LOA as "Other" in CMB-OMM. These comparisons show reasonable consistency although with significant scatter on a dayto-day basis. The slopes are close to one in most cases, with Woodsmoke/BBOA showing a lower slope (with PMFAMS $>$ CMB-OMM as indicated by the regression line), yet having the highest level of correlation, likely due to the relatively large dynamic range. The lower estimate of Woodsmoke OA from CMB-OOM may be due to the use of levoglucosan as a tracer based on source measurements, since some degradation of this tracer is observed in ambient studies (Cubison et al., 2008b). The PMF-AMS method conceptually determines the levoglucosan level in BBOA from the ambient measurements and thus is less prone to such underestimation. The lowest $R^{2}$ is found for the HOA/Vehicle POA comparison, which may be due to the lower dynamic range of this source which is always present in the urban area and perhaps to the influence of non-vehicle sources of HOA. Additional possible reasons for differences for the daily source contributions include variations in the $\mathrm{OM} / \mathrm{OC}$ ratios vs. the constant values assumed here for the conversion of $\mathrm{CMB}$ sources to $\mathrm{OA}$, uncertainties and noise in both the tracer measurements and AMS spectra, and imperfections in the CMB-OMM and PMF-AMS source attribution algorithms and their application to real data (e.g. Ulbrich et al., 2009). Finally, it is possible that the different PMF-AMS OA components could have slightly different relative ionization efficiencies (RIEs), and/or bounce-related 


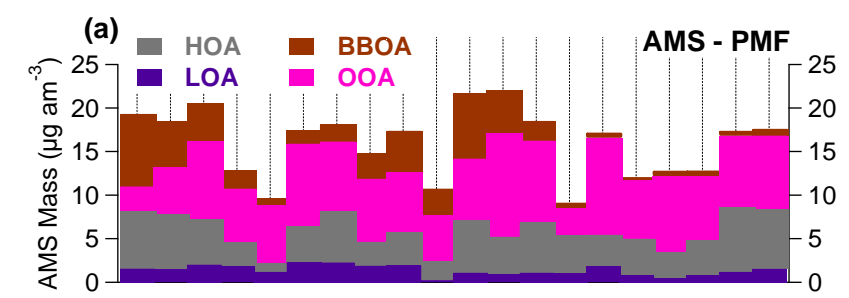

(c)

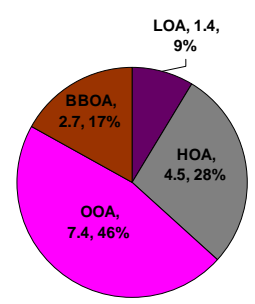

(b) Vegetative Detritus

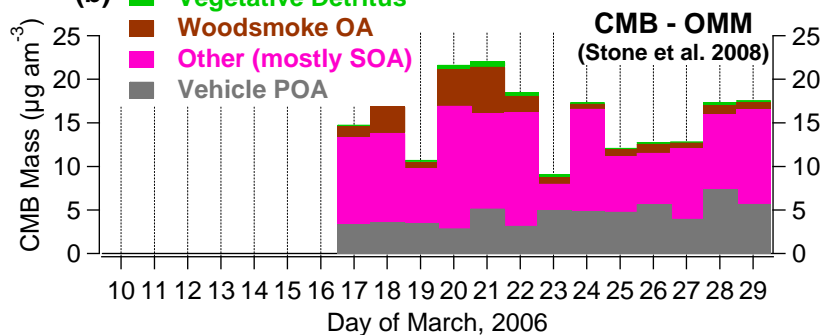

(d)

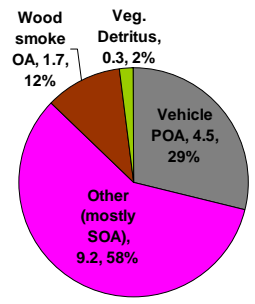

Fig. 12. Daily source apportionment of OA from (a) PMF-AMS and (b) CMB-OMM with (c, d) the average composition of each, respectively, for the overlapping sampling period from 17-30 March. Note: CMB-OMM OC results converted to OM (Aiken et al., 2008).

collection efficiencies $\left(E_{b}\right)$ to the extent that they are present in externally mixed particles. Both of these effects would lead to a positive bias of the chemically-reduced and more volatile components (HOA, BBOA, LOA) and a negative bias against OOA (Jimenez et al., 2003; Huffman et al., 2005, 2009a; Zhang et al., 2005b). We experimented with different $E_{b} *$ RIE for the different OA components retrieved by PMF, but the comparisons with other measurements (Table S-1 and Figs. S-2, S-3, and S-4) were not significantly improved. Thus, any variations in the product $E_{b} *$ RIE for the different organic species are estimated to be small and not the main reason for the differences observed in some of the intercomparisons. This is consistent with the analysis by Docherty et al. (2009) for an AMS dataset in Riverside, CA, who estimate that the biases in OA component quantification due to the differences in $E_{b} *$ RIE between different PMF-AMS OA components are less than $15 \%$. Overall the agreement between both techniques for such a complex urban area given all the remaining uncertainties is very encouraging.

\subsection{Comparisons with Mexico City emissions inventory}

We can use the PMF-AMS OA results to evaluate the 2006 Mexico City emissions inventory (SMA 2006). Since most of the PM species and components vary slowly in time (Fig. 1), are observed at consistent ratios at different times during the campaign, and show similar fractions and ratios to the data from MCMA-2003 from a different location in the city, we conclude that our observations at T0 are generally representative for Mexico City. The 2006 MCMA emissions inventory attributes $62 \%$ of the $\mathrm{PM}_{2.5}$ emissions to motor vehicles and most of the rest to a variety of area and point sources, whose activity is not expected to be strongly dependent on the time of the year. When HOA, LOA, submicron soil, metals, and BC mass concentrations are summed dur-
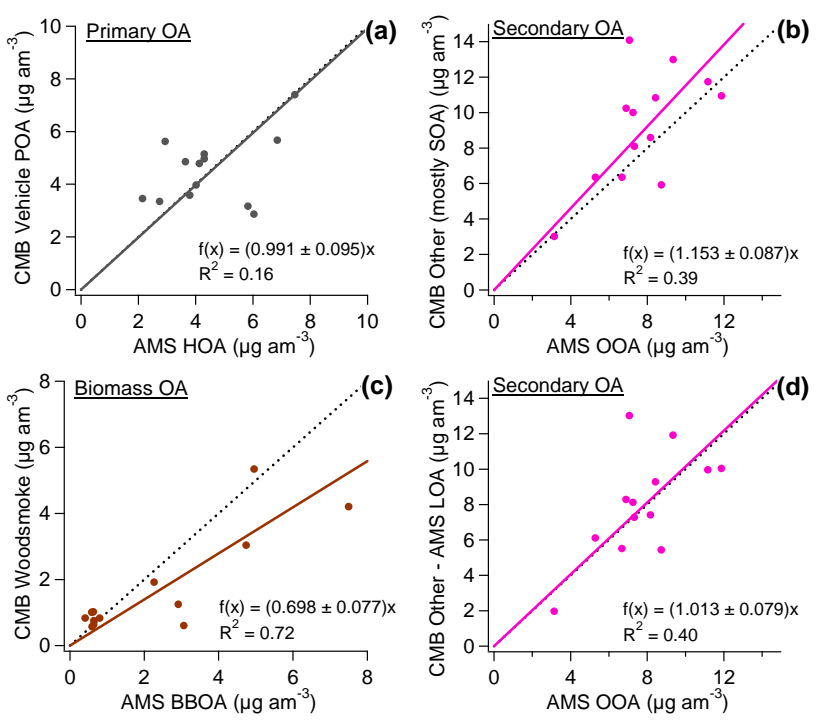

Fig. 13. Scatter plots and linear orthogonal distance regressions of source apportionment factors from CMB-OMM versus the corresponding PMF-AMS source: (a) Vehicle POA and HOA, (b) Other (mostly SOA) and OOA, (c) Woodsmoke and BBOA, (d) CMB-Other minus AMS-LOA vs. AMS-OOA. (Dashed lines are 1:1 lines.)

ing the morning rush hour period (06:00-08:00 a.m.), which is most strongly influenced by direct emissions, we obtain a $\mathrm{PM} / \Delta \mathrm{CO}$ ratio of $11.5 \mu \mathrm{g} \mathrm{am}^{-3} \mathrm{ppm}^{-1}(13 \mathrm{~g} / \mathrm{kg})$. The 2006 emissions inventory has a primary $\mathrm{PM}_{2.5} / \Delta \mathrm{CO}$ emission ratio of $3.1 \mathrm{~g} / \mathrm{kg}$ (equivalent to $2.7 \mu \mathrm{g} \mathrm{am}^{-3} \mathrm{ppm}^{-1}$ ). Since the $\mathrm{CO}$ emissions inventory is thought to be accurate (de Foy et al., 2007), this implies that the primary PM is underestimated by about a factor of four in the 2006 emissions inventory. Since several of the species included in this sum are submicron or (such as BC) do not extend to $2.5 \mu \mathrm{m}$, the calculated underestimation of the emission inventory is a lower limit, 
as additional small amounts of those species in the $\mathrm{PM}_{1}$ to $\mathrm{PM}_{2.5}$ range would increase the measured-to-inventory ratio. This underestimate is consistent with the results of Zavala et al. (2009) for the mobile source emission inventory. If we add in the secondary aerosol production as determined from the peak in the afternoon by summing the additional OOA, ammonium nitrate and ammonium chloride concentrations (PM/ $\Delta \mathrm{CO}$ ratio of $44 \mu \mathrm{g} \mathrm{am}^{-3} \mathrm{ppm}^{-1}$ for those species), the MCMA PM in the afternoon exceeds the amount that would be predicted with the 2006 emissions inventory by a factor of $\sim 16$. Additionally, the forest fire source in the 2006 MCMA emissions inventory is small (2\% of the primary $\left.\mathrm{PM}_{2.5}\right)$ and is much smaller (by at least an order-of-magnitude) than our observations, which is quantified further in the companion paper (Aiken et al., 2009).

\subsection{Rapid estimation of PMF-AMS components from UMR tracer $m / z$}

Zhang et al. (2005a) provided a simple approximation to estimate the HOA and OOA concentrations based on the time series of UMR $m / z 44$ and $57(\mathrm{OOA}=7.6 \times \mathrm{m} / \mathrm{z} 44$ and HOA $=12.2 \times m / z 57$, when $\mathrm{m} / z 44$ and 57 are in units of org.eq. $\mu \mathrm{g} \mathrm{m}^{-3}$, Zhang et al., 2005a). Since this is the first study in which PMF has been applied to high-resolution data and also one of the firsts in which BBOA has been explicitly identified in urban air, it is of interest to update the estimation procedure using the results of this study. Figure $14 a-d$ show scatter plots used to derive relationships to estimate OOA, BBOA, and HOA based on linear combinations of $m / z 44$, 57 , and 60 , which are qualitatively consistent with the results of Zhang et al. (2005a, b) although the coefficients are different in this case. OOA is estimated as proportional to UMR $m / z 44$, with an offset likely due to ions other than $\mathrm{CO}_{2}^{+}$at this $m / z$ (Fig. 14a). BBOA is estimated as proportional to $\mathrm{m} / \mathrm{z} 60$, after subtracting a background of $0.3 \%$ of the OA for this ion, mainly due to SOA (Docherty et al., 2008) (Fig. 14b). HOA is estimated as proportional to the $\mathrm{C}_{4} \mathrm{H}_{9}^{+}$ion at $m / z 57$ (Fig. $14 \mathrm{~d}$ ), which is estimated as the total UMR signal at $m / z 57$ minus $10 \%$ of UMR $\mathrm{m} / z 44$ (as an estimate of the $\mathrm{C}_{3} \mathrm{H}_{5} \mathrm{O}^{+}$ion at $\mathrm{m} / 257$, Fig. $14 \mathrm{c}$ ).

Figure $14 \mathrm{e}$ compares the time series of OOA, BBOA, and HOA estimated in this way to those derived with the full PMF analysis of the HR data. It is clear that the tracer-based method with the coefficients determined here is capable of providing a good first-order estimate of the OA components based on the UMR data which can be very useful during field studies and early analyses before the full (and very timeconsuming) HR and PMF analyses have been performed. However, the coefficients are not known a priori. Due to the difference in the actual coefficients determined here vs. those determined by Zhang et al. (2005a) for Pittsburgh, it is of great interest to report the results of this analysis for other locations in order to establish the range of variation of the
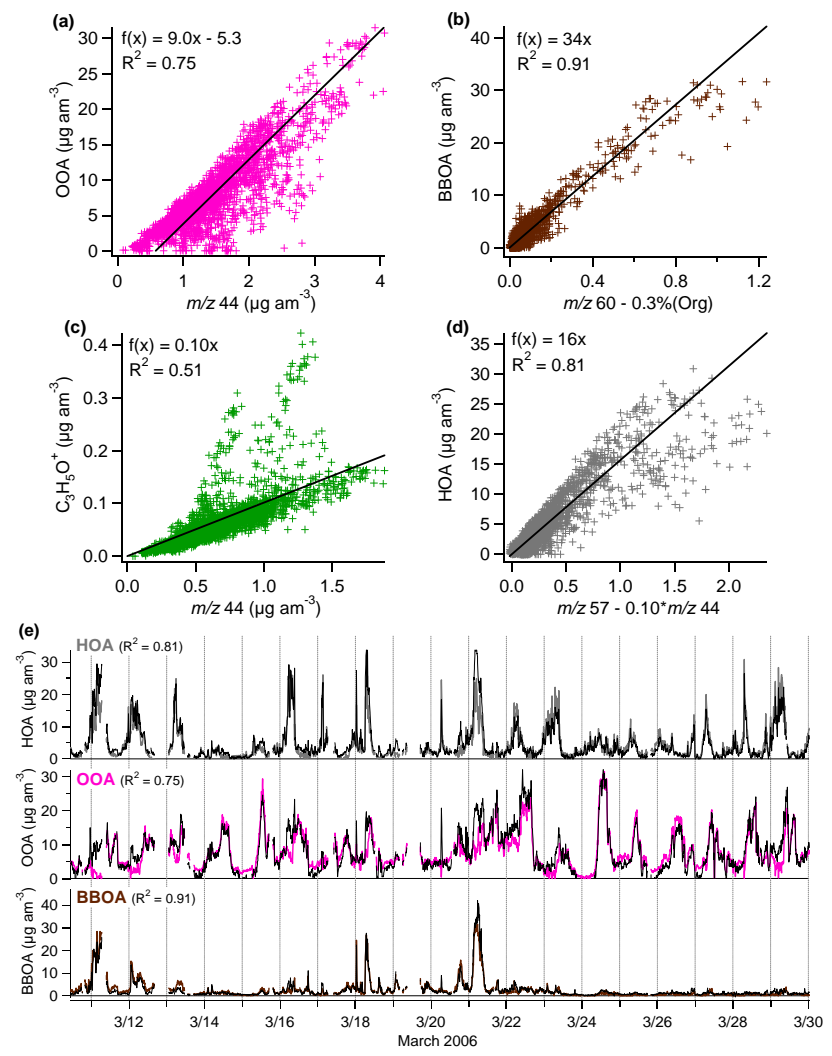

Fig. 14. Relationships between PMF-AMS components and tracer $\mathrm{m} / \mathrm{z}$ from UMR spectra: (a) OOA vs. UMR $\mathrm{m} / \mathrm{z} 44$; (b) BBOA vs. UMR $m / z 60$ minus $0.3 \% *$ Org; (c) relationship between the $\mathrm{C}_{3} \mathrm{H}_{5} \mathrm{O}^{+}$ion at $\mathrm{m} / z, 57$ and $\mathrm{UMR} \mathrm{m} / z 44$, which is used to correct for the influence of OOA in UMR $\mathrm{m} / z 57$; (d) HOA vs. OOA-corrected UMR $m / z 57$; (e) comparison of the time series of the HR PMFAMS factors (presented in this paper) versus the factors predicted from the UMR tracer $m / z$ 's with the relationships derived here.

coefficients, as well as dependences on photochemical age, type of POA and BBOA sources, etc.

\section{Conclusions}

Continuous ambient aerosol measurements were made during MILAGRO at the T0 supersite within Mexico City during March 2006. Intercomparisons confirm that the AMS performed well at T0, and that the scatter of the AMS versus other measurements is similar to that amongst the other measurements. Refractory species account for $20 \%$ of the average $33.7 \mu \mathrm{g} \mathrm{am}^{-3} \mathrm{PM}_{1}$ (BC: $12 \%$, metals: $3 \%$, soil: $5 \%$ ). The species mass concentrations, size distributions, and diurnal profiles were similar to those measured during MCMA2003 at CENICA, with OA accounting for about half of the submicron mass (Salcedo et al., 2006). PMF-AMS analysis of the high-resolution mass spectra was used to separate four organic components, which are consistent with previous studies in Mexico City and elsewhere. The assignments of the four components are supported by their mass spectra, 
time series correlations with tracers, and other evidence such as tracer ratios. HOA (primary hydrocarbon-like), OOA (oxygenated, mostly secondary), BBOA (biomass burning, which likely includes both forest fires and some refuse burning), and a small local nitrogen-containing OA (LOA) primary source were identified. LOA likely contains amines and accounts for $1 / 3$ of the detected nitrogen in the OA. Primary emissions and secondary OA formation are both important for this dataset. The impact of biomass burning is significant for OA and is highly variable in time, consistent with other ground-based observations during MILAGRO (Stone et al., 2008; de Gouw et al., 2009). The AMS averages and trends compare well to those from CMB of organic molecular markers, although with significant scatter in the daily comparisons. The 2006 MCMA emissions inventory is underestimated by a factor of $\sim 4$ for primary fine PM and lower than the afternoon concentrations by $\sim 16$ when secondary species are included. Additional secondary species formation over longer time scales (e.g. Dzepina et al., 2009) will likely increase this ratio. The forest fire PM from the MCMA inventory is at least an order-of-magnitude lower than that estimated from our observations. A simple estimation method based on UMR tracer $m / z$ 's can provide a first-order approximation of the PMF components and should be explored for other locations.

Acknowledgements. This study was supported by the following funding, NASA: fellowship NNG04GR06H (ACA), NGT5-30516 (JAH), NNG05GQ50H (IMU); NSF: grants ATM-0528634, ATM-0449815 (CAREER), ATM-0511769 (WPA and GPM), ATM-0528227 (LTM) and ATM-0511803 (LTM); DOE: grants DE-FG02-05ER63981 and DE-FG02-05ER64008 (WPA and GPM); NOAA: grant NA08OAR4310565; and EPA STAR fellowship RD-83216101-0 (PFD). PIXE analysis was performed in the Environmental Molecular Sciences Laboratory, a national scientific user facility sponsored by OBER/DOE and located at Pacific Northwest National Laboratory. Although this research has been partially funded by EPA and NSF, it has not been subject to Agency Review and thus no official endorsement should be inferred. We are grateful to X. Querol for the OPC data. The authors would also like to thank support from and useful discussions with Aerodyne, Tofwerk, J. de Gouw, and the remainder of the Jimenez Group. Finally, we would like to acknowledge IMP for hosting the T0 Supersite and the logistical support from many Mexican government agencies and institutions which made it possible to carry out the MCMA-2006/MILAGRO Campaign.

Edited by: S. Madronich

\section{References}

Aiken, A. C., de Foy, B., Wiedinmyer, C., et al.: Mexico City aerosol analysis during MILAGRO using high resolution aerosol mass spectrometry at the urban supersite (T0) - Part 2: Analysis of the biomass burning contribution and the modern carbon fraction, Atmos. Chem. Phys., in preparation, 2009.

Aiken, A. C., DeCarlo, P. F. and Jimenez, J. L.: Elemental Analysis of Organic Species with Electron Ionization High-Resolution,
Mass Spectrometry, Anal. Chem., 79(21), 8350-8358, 2007.

Aiken, A. C., DeCarlo, P. F., Kroll, J. H., et al.: O/C and OM/OC Ratios of Primary, Secondary, and Ambient Organic Aerosols with High-Resolution Time-of-Flight Aerosol Mass Spectrometry, Environ. Sci. Technol., 42(12), 4478-4485, doi:10.1021/es703009q, 2008.

Alfarra, M. R., Prevot, A. S. H., Szidat, S., Sandradewi, J., Weimer, S., Lanz, V. A., Schreiber, D., Mohr, M., and Baltensperger, U.: Identification of the mass spectral signature of organic aerosols from wood burning emissions, Environ. Sci. Technol., 41(16), 5770-5777, 2007.

Allan, J. D., Delia, A. E., Coe, H., et al.: Technical note: A generalised method for the extraction of chemically resolved mass spectra from aerodyne aerosol mass spectrometer data, J. Aerosol Sci., 35(7), 909-922, 2004.

Bravo, A. H., Sosa, E. R., Sanchez, A. P., Jaimes, P. M., and Saavedra, R. M. I.: Impact of wildfires on the air quality of Mexico City, 1992-1999, Environ. Pollut., 117(2), 243-253, 2002.

Canagaratna, M. R., Jayne, J. T., Jimenez, J. L., et al.: Chemical and microphysical characterization of ambient aerosols with the aerodyne aerosol mass spectrometer, Mass Spectrom. Rev., 26(2), 185-222, 2007.

Capes, G., Johnson, B., McFiggans, G., Williams, P. I., Haywood, J., and Coe, H.: Aging of biomass burning aerosols over West Africa: Aircraft measurements of chemical composition, microphysical properties, and emission ratios, J. Geophys. Res.Atmos., 113, D00C15, doi:10.1029/2008JD009845, 2008.

Chow, J. C., Watson, J. G., Edgerton, S. A., and Vega, E.: Chemical composition of PM2.5 and PM10 in Mexico City during winter 1997, Sci. Total Environ., 287(3), 177-201, 2002.

Crounse, J. D., DeCarlo, P. F., Blake, D. R., Emmons, L. K., Campos, T. L., Apel, E. C., Clarke, A. D., Weinheimer, A. J., McCabe, D. C., Yokelson, R. J., Jimenez, J. L., and Wennberg, P. O.: Biomass burning and urban air pollution over the Central Mexican Plateau, Atmos. Chem. Phys., 9, 4929-4944, 2009, http://www.atmos-chem-phys.net/9/4929/2009/.

Cubison, M. J., Ervens, B., Feingold, G., Docherty, K. S., Ulbrich, I. M., Shields, L., Prather, K., Hering, S., and Jimenez, J. L.: The influence of chemical composition and mixing state of Los Angeles urban aerosol on CCN number and cloud properties, Atmos. Chem. Phys., 8, 5649-5667, 2008a, http://www.atmos-chem-phys.net/8/5649/2008/.

Cubison, M. J., Sueper, D., Dunlea, E. J., et al.: Submicron aerosol composition during the ARCTAS campaign: Arctic Haze, Biomass Burning, and California Pollution, Eos Trans. AGU, 89, 53, Fall Meet. Suppl., Abstract A11A-0081, 2008b.

de Foy, B., Caetano, E., Magãa, V., Zitácuaro, A., Cárdenas, B., Retama, A., Ramos, R., Molina, L. T., and Molina, M. J.: Mexico City basin wind circulation during the MCMA-2003 field campaign, Atmos. Chem. Phys., 5, 2267-2288, 2005, http://www.atmos-chem-phys.net/5/2267/2005/.

de Foy, B., Clappier, A., Molina, L. T., and Molina, M. J.: Distinct wind convergence patterns in the Mexico City basin due to the interaction of the gap winds with the synoptic flow, Atmos. Chem. Phys., 6, 1249-1265, 2006a, http://www.atmos-chem-phys.net/6/1249/2006/.

de Foy, B., Fast, J. D., Paech, S. J., Phillips, D., Walters, J. T., Coulter, R. L., Martin, T. J., Pekour, M. S., Shaw, W. J., Kastendeuch, P. P., Marley, N. A., Retama, A., and Molina, L. T.: Basin- 
scale wind transport during the MILAGRO field campaign and comparison to climatology using cluster analysis, Atmos. Chem. Phys., 8, 1209-1224, 2008, http://www.atmos-chem-phys.net/8/1209/2008/.

de Foy, B., Lei, W., Zavala, M., Volkamer, R., Samuelsson, J., Mellqvist, J., Galle, B., Martínez, A.-P., Grutter, M., Retama, A., and Molina, L. T.: Modelling constraints on the emission inventory and on vertical dispersion for $\mathrm{CO}$ and $\mathrm{SO}^{2}$ in the Mexico City Metropolitan Area using Solar FTIR and zenith sky UV spectroscopy, Atmos. Chem. Phys., 7, 781-801, 2007,

http://www.atmos-chem-phys.net/7/781/2007/.

de Foy, B., Varela, J. R., Molina, L. T., and Molina, M. J.: Rapid ventilation of the Mexico City basin and regional fate of the urban plume, Atmos. Chem. Phys., 6, 2321-2335, 2006b, http://www.atmos-chem-phys.net/6/2321/2006/.

de Foy, B., Zavala, M., Bei, N., and Molina, L. T.: Evaluation of WRF mesoscale simulations and particle trajectory analysis for the MILAGRO field campaign, Atmos. Chem. Phys., 9, 44194438, 2009, http://www.atmos-chem-phys.net/9/4419/2009/.

de Gouw, J. and Jimenez, J. L.: Organic Aerosols in the Earth's Atmosphere, Environ. Sci. Technol., in press, 2009.

de Gouw, J. A., Middlebrook, A. M., Warneke, C., et al.: Budget of organic carbon in a polluted atmosphere: Results from the New England Air Quality Study in 2002, J. Geophys. Res.-Atmos., 110, D16305, doi:10.1029/2004JD005623 2005.

de Gouw, J. A., Welsh-Bon, D., Warneke, C., Kuster, W. C., Alexander, L., Baker, A. K., Beyersdorf, A. J., Blake, D. R., Canagaratna, M., Celada, A. T., Huey, L. G., Junkermann, W., Onasch, T. B., Salcido, A., Sjostedt, S. J., Sullivan, A. P., Tanner, D. J., Vargas, O., Weber, R. J., Worsnop, D. R., Yu, X. Y., and Zaveri, R.: Emission and chemistry of organic carbon in the gas and aerosol phase at a sub-urban site near Mexico City in March 2006 during the MILAGRO study, Atmos. Chem. Phys., 9, 3425-3442, 2009,

http://www.atmos-chem-phys.net/9/3425/2009/.

de Foy, B., Caetano, E., Maga a, V., Zitácuaro, A., Cárdenas, B., Retama, A., Ramos, R., Molina, L. T., and Molina, M. J.: Mexico City basin wind circulation during the MCMA-2003 field campaign, Atmos. Chem. Phys., 5, 2267-2288, 2005, http://www.atmos-chem-phys.net/5/2267/2005/.

DeCarlo, P. F., Dunlea, E. J., Kimmel, J. R., Aiken, A. C., Sueper, D., Crounse, J., Wennberg, P. O., Emmons, L., Shinozuka, Y., Clarke, A., Zhou, J., Tomlinson, J., Collins, D. R., Knapp, D., Weinheimer, A. J., Montzka, D. D., Campos, T., and Jimenez, J. L.: Fast airborne aerosol size and chemistry measurements above Mexico City and Central Mexico during the MILAGRO campaign, Atmos. Chem. Phys., 8, 4027-4048, 2008,

http://www.atmos-chem-phys.net/8/4027/2008/.

DeCarlo, P. F., Kimmel, J. R., Trimborn, A., et al.: Fielddeployable, high-resolution, time-of-flight aerosol mass spectrometer, Anal. Chem., 78(24), 8281-8289, 2006.

DeCarlo, P. F., Slowik, J. G., Worsnop, D. R., Davidovits, P., and Jimenez, J. L.: Particle morphology and density characterization by combined mobility and aerodynamic diameter measurements. Part 1: theory, Aerosol Sci. Tech., 38, 1185-1205, 2004.

Docherty, K. S., Stone, E. A., Ulbrich, I. M., et al.: Apportionment of primary and secondary organic aerosols in southern California during the 2005 study of organic aerosols in Riverside (SOAR), Environ. Sci. Technol., 42, 7655-7662, 2008.
Drewnick, F., Hings, S. S., DeCarlo, P., et al.: A new time-of-flight aerosol mass spectrometer (TOF-AMS) - Instrument description and first field deployment, Aerosol Sci. Tech., 39(7), 637-658, 2005.

Dunlea, E. J., DeCarlo, P. F., Aiken, A. C., Kimmel, J. R., Peltier, R. E., Weber, R. J., Tomlison, J., Collins, D. R., Shinozuka, Y., McNaughton, C. S., Howell, S. G., Clarke, A. D., Emmons, L. K., Apel, E. C., Pfister, G. G., van Donkelaar, A., Martin, R. V., Millet, D. B., Heald, C. L., and Jimenez, J. L.: Evolution of Asian aerosols during transpacific transport in INTEX-B, Atmos. Chem. Phys. Discuss., 8, 15375-15461, 2008,

http://www.atmos-chem-phys-discuss.net/8/15375/2008/.

Dzepina, K., Volkamer, R. M., Madronich, S., Tulet, P., Ulbrich, I. M., Zhang, Q., Cappa, C. D., Ziemann, P. J., and Jimenez, J. L.: Evaluation of recently-proposed secondary organic aerosol models for a case study in Mexico City, Atmos. Chem. Phys., 9, 5681-5709, 2009,

http://www.atmos-chem-phys.net/9/5681/2009/.

Edgerton, S. A., Bian, X., Doran, J. C., et al.: Particulate air pollution in Mexico City: A collaborative research project, J. Air Waste Manage., 49(10), 1221-1229, 1999.

Farmer, D. K., Docherty, K. S., Cubison, M. J., Ziemann, P. J., Matsunaga, A., and Jimenez, J. L.: Aerosol organic nitrate characterization and quantification with the High Resolution-Time of Flight-Aerosol Mass Spectrometer, Fall Meeting Suppl. Abstract A31B-0092, EOS T. Am. Geophys. Un., 2008.

Fast, J. D., de Foy, B., Acevedo Rosas, F., Caetano, E., Carmichael, G., Emmons, L., McKenna, D., Mena, M., Skamarock, W., Tie, X., Coulter, R. L., Barnard, J. C., Wiedinmyer, C., and Madronich, S.: A meteorological overview of the MILAGRO field campaigns, Atmos. Chem. Phys., 7, 2233-2257, 2007, http://www.atmos-chem-phys.net/7/2233/2007/.

Fast, J. D. and Zhong, S. Y.: Meteorological factors associated with inhomogeneous ozone concentrations within the Mexico City basin, J. Geophys. Res.-Atmos., 103(D15), 18927-18946, 1998.

Fast, J., Aiken, A. C., Allan, J., Alexander, L., Campos, T., Canagaratna, M. R., Chapman, E., DeCarlo, P. F., de Foy, B., Gaffney, J., de Gouw, J., Doran, J. C., Emmons, L., Hodzic, A., Herndon, S. C., Huey, G., Jayne, J. T., Jimenez, J. L., Kleinman, L., Kuster, W., Marley, N., Russell, L., Ochoa, C., Onasch, T. B., Pekour, M., Song, C., Ulbrich, I. M., Warneke, C., WelshBon, D., Wiedinmyer, C., Worsnop, D. R., Yu, X.-Y., and Zaveri, R.: Evaluating simulated primary anthropogenic and biomass burning organic aerosols during MILAGRO: implications for assessing treatments of secondary organic aerosols, Atmos. Chem. Phys., 9, 6191-6215, 2009,

http://www.atmos-chem-phys.net/9/6191/2009/.

Fine, P. M., Sioutas, C., and Solomon, P. A.: Secondary particulate matter in the United States: Insights from the particulate matter supersites program and related studies, J. Air Waste Manage., 58(2), 234-253, 2008.

Fortner, E. C., Zheng, J., Zhang, R., Berk Knighton, W., Volkamer, R. M., Sheehy, P., Molina, L., and André, M.: Measurements of Volatile Organic Compounds Using Proton Transfer Reaction Mass Spectrometry during the MILAGRO 2006 Campaign, Atmos. Chem. Phys., 9, 467-481, 2009, http://www.atmos-chem-phys.net/9/467/2009/.

Fountoukis, C., Nenes, A., Sullivan, A., Weber, R., Van Reken, T., Fischer, M., Matas, E., Moya, M., Farmer, D., and Cohen, R. C.: 
Thermodynamic characterization of Mexico City aerosol during MILAGRO 2006, Atmos. Chem. Phys., 9, 2141-2156, 2009, http://www.atmos-chem-phys.net/9/2141/2009/.

Gilardoni, S., Liu, S., Takahama, S., Russell, L. M., Allan, J. D., Steinbrecher, R., Jimenez, J. L., De Carlo, P. F., Dunlea, E. J., and Baumgardner, D.: Characterization of organic ambient aerosol during MIRAGE 2006 on three platforms, Atmos. Chem. Phys., 9, 5417-5432, 2009, http://www.atmos-chem-phys.net/9/5417/2009/.

Grieshop, A. P., Donahue, N. M., and Robinson, A. L.: Laboratory investigation of photochemical oxidation of organic aerosol from wood fires 2: analysis of aerosol mass spectrometer data, Atmos. Chem. Phys., 9, 2227-2240, 2009,

http://www.atmos-chem-phys.net/9/2227/2009/.

Hallquist, M., Wenger, J. C., Baltensperger, U., Rudich, Y., Simpson, D., Claeys, M., Dommen, J., Donahue, N. M., George, C., Goldstein, A. H., Hamilton, J. F., Herrmann, H., Hoffmann, T., Iinuma, Y., Jang, M., Jenkin, M. E., Jimenez, J. L., Kiendler-Scharr, A., Maenhaut, W., McFiggans, G., Mentel, Th. F., Monod, A., Prévôt, A. S. H., Seinfeld, J. H., Surratt, J. D., Szmigielski, R., and Wildt, J.: The formation, properties and impact of secondary organic aerosol: current and emerging issues, Atmos. Chem. Phys., 9, 5155-5235, 2009,

http://www.atmos-chem-phys.net/9/5155/2009/.

Hennigan, C. J., Sullivan, A. P., Fountoukis, C. I., Nenes, A., Hecobian, A., Vargas, O., Peltier, R. E., Case Hanks, A. T., Huey, L. G., Lefer, B. L., Russell, A. G., and Weber, R. J.: On the volatility and production mechanisms of newly formed nitrate and water soluble organic aerosol in Mexico City, Atmos. Chem. Phys., 8, 3761-3768, 2008,

http://www.atmos-chem-phys.net/8/3761/2008/.

Herndon, S. C., Onasch, T. B., Wood, E. C., et al.: The Correlation of Secondary Organic Aerosol with Odd Oxygen in a Megacity Outflow, Geophys Res. Lett., 35, L15804, doi:10.1029/2008GL034058, 2008.

Hodzic, A., Jimenez, J. L., Madronich, S., Aiken, A. C., Bessagnet, B., Curci, G., Fast, J., Lamarque, J. F., Onasch, T. B., Roux, G., and Ulbrich, I. M.: Modeling organic aerosols during MILAGRO: application of the CHIMERE model and importance of biogenic secondary organic aerosols, Atmos. Chem. Phys. Discuss., 9, 12207-12281, 2009, http://www.atmos-chem-phys-discuss.net/9/12207/2009/.

Huffman, J. A., Docherty, K. S., Aiken, A. C., Cubison, M. J., Ulbrich, I. M., DeCarlo, P. F., Sueper, D., Jayne, J. T., Worsnop, D. R., Ziemann, P. J., and Jimenez, J. L.: Chemically-resolved aerosol volatility measurements from two megacity field studies, Atmos. Chem. Phys. Discuss., 9, 2645-2697, 2009a, http://www.atmos-chem-phys-discuss.net/9/2645/2009/.

Huffman, J. A., Docherty, K. S., Mohr, C., Cubison, M. J., U1brich, I. M., Ziemann, P. J., Onasch, T. B., and Jimenez, J. L.: Chemically-Resolved Volatility Measurements of Organic Aerosol from Different Sources, Environ. Sci. Technol., 43, 5351-5357, doi:10.1021/es803539d, 2009b.

Huffman, J. A., Jayne, J. T., Drewnick, F., Aiken, A. C., Onasch, T., Worsnop, D. R., and Jimenez, J. L.: Design, modeling, optimization, and experimental tests of a particle beam width probe for the aerodyne aerosol mass spectrometer, Aerosol Sci. Tech., 39(12), 1143-1163, 2005.

Huffman, J. A., Ziemann, P. J., Jayne, J. T., Worsnop, D. R., and Jimenez, J. L.: Development and characterization of a fast-stepping/scanning thermodenuder for chemically-resolved aerosol volatility measurements, Aerosol Sci. Tech., 42, 395407, 2008.

IPCC: Climate Change 2007 - The Physical Science Basis. Working Group I Contribution to the Fourth Assessment Report of the IPCC, Cambridge University Press, Cambridge, UK, 2007.

Jayne, J. T., Leard, D. C., Zhang, X. F., Davidovits, P., Smith, K. A., Kolb, C. E., and Worsnop, D. R.: Development of an aerosol mass spectrometer for size and composition analysis of submicron particles, Aerosol Sci. Tech., 33(1-2), 49-70, 2000.

Jimenez, J. L., Jayne, J. T., Shi, Q., et al.: Ambient aerosol sampling using the Aerodyne Aerosol Mass Spectrometer, J. Geophys. Res.-Atmos., 108(D7), 8425, doi:8410.1029/2001JD001213, 2003.

Johnson, K. S., de Foy, B., Zuberi, B., Molina, L. T., Molina, M. J., Xie, Y., Laskin, A., and Shutthanandan, V.: Aerosol composition and source apportionment in the Mexico City Metropolitan Area with PIXE/PESA/STIM and multivariate analysis, Atmos. Chem. Phys., 6, 4591-4600, 2006,

http://www.atmos-chem-phys.net/6/4591/2006/.

Johnson, K. S., Laskin, A., Jimenez, J. L., Shutthanandan, V., Molina, L. T., Salcedo, D., Dzepina, K., and Molina, M. J.: Comparative analysis of urban atmospheric aerosol by ProtonInduced X-ray Emission (PIXE), Proton Elastic Scattering Analysis (PESA), and Aerosol Mass Spectrometry (AMS), Environ. Sci. Technol., 42, 6619-6624, doi:10.1021/es800393e, 2008.

Khlystov, A., Zhang, Q., Jimenez, J. L., Stanier, C., Pandis, S. N., Canagaratna, M. R., Fine, P., Misra, C., and Sioutas, C.: In situ concentration of semi-volatile aerosol using water-condensation technology, J. Aerosol Sci., 36(7), 866-880, 2005.

Kleinman, L. I., Springston, S. R., Daum, P. H., Lee, Y.-N., Nunnermacker, L. J., Senum, G. I., Wang, J., Weinstein-Lloyd, J., Alexander, M. L., Hubbe, J., Ortega, J., Canagaratna, M. R., and Jayne, J.: The time evolution of aerosol composition over the Mexico City plateau, Atmos. Chem. Phys., 8, 1559-1575, 2008, http://www.atmos-chem-phys.net/8/1559/2008/.

Knighton, W. B., Fortner, E. C., Herndon, S. C., et al.: Examination of biomass burning tracer signatures in urban environments, EOS Trans. AGU. Abstract A33D-1569, Fall Meet. Suppl., 88(52), 2007.

Kondo, Y., Miyazaki, Y., Takegawa, N., Miyakawa, T., Weber, R. J., Jimenez, J. L., Zhang, Q., and Worsnop, D. R.: Oxygenated and water-soluble organic aerosols in Tokyo, J. Geophys. Res.Atmos., 112, D01203, doi:10.1029/2006JD007056, 2007.

Kroll, J. H., Smith, J. D., Wilson, K. R., et al.: Evolution of Diesel Exhaust Aerosol in an Urban Environment, EOS T. Am. Geophys. Un., Abstract A31E-02, Fall Meet. Suppl., 2007.

Lanz, V. A., Alfarra, M. R., Baltensperger, U., Buchmann, B., Hueglin, C., and Prévôt, A. S. H.: Source apportionment of submicron organic aerosols at an urban site by factor analytical modelling of aerosol mass spectra, Atmos. Chem. Phys., 7, 15031522, 2007, http://www.atmos-chem-phys.net/7/1503/2007/.

Lonati, G., Ozgen, S., and Giugliano, M.: Primary and secondary carbonaceous species in PM2.5 samples in Milan (Italy), Atmos. Environ., 41(22), 4599-4610, 2007.

Madronich, S.: Chemical evolution of gaseous air pollutants downwind of tropical megacities: Mexico City case study, Atmos. Environ., 40(31), 6012-6018, 2006. 
Malm, W. C., Sisler, J. F., Huffman, D., Eldred, R. A., and Cahill, T. A.: Spatial and Seasonal Trends in Particle Concentration and Optical Extinction in the United-States, J. Geophys. Res.Atmos., 99(D1), 1347-1370, 1994.

Marley, N. A., Gaffney, J. S., Castro, T., Salcido, A., and Frederick, J.: Measurements of aerosol absorption and scattering in the Mexico City Metropolitan Area during the MILAGRO field campaign: a comparison of results from the T0 and T1 sites, Atmos. Chem. Phys., 9, 189-206, 2009,

http://www.atmos-chem-phys.net/9/189/2009/.

McLafferty, F. W. and Turecek, F.: Interpretation of mass spectra, University Science Books, Mill Valley, CA, 1993.

Moffet, R. C., de Foy, B., Molina, L. T., Molina, M. J., and Prather, K. A.: Measurement of ambient aerosols in northern Mexico City by single particle mass spectrometry, Atmos. Chem. Phys., 8, 4499-4516, 2008a,

http://www.atmos-chem-phys.net/8/4499/2008/.

Moffet, R. C., Desyaterik, Y., Hopkins, R. J., et al. Characterization of Aerosols Containing $\mathrm{Zn}, \mathrm{Pb}$, and $\mathrm{Cl}$ from an Industrial $\mathrm{Re}-$ gion of Mexico City, Environ. Sci. Technol., 42(19), 7091-7097, 2008b.

Mohr, C., Huffman, J. A., Cubison, M. J., Aiken, A. C., Docherty, K. S., Kimmel, J. R., Ulbrich, I. M., Hannigan, M., and Jimenez, J. L.: Characterization of primary organic aerosol emissions from meat cooking, trash burning, and motor vehicles with highresolution aersol mass spectrometry and comparison with ambient and chamber observations, Environ. Sci. Technol., 43, 24432449, doi:10.1021/es8011518, 2009.

Molina, L. T., Kolb, C. E., de Foy, B., Lamb, B. K., Brune, W. H., Jimenez, J. L., Ramos-Villegas, R., Sarmiento, J., ParamoFigueroa, V. H., Cardenas, B., Gutierrez-Avedoy, V., and Molina, M. J.: Air quality in North America's most populous city overview of the MCMA-2003 campaign, Atmos. Chem. Phys., 7, 2447-2473, 2007,

http://www.atmos-chem-phys.net/7/2447/2007/.

Molina, L. T., Madronich, S., Gaffney, J. S., and Singh, H. B.: Overview of MILAGRO/INTEX-B Campaign, IGACtivities Newsletter, 38, 2-15, 2008.

Molina, L. T. and Molina, M. J.: Air quality impacts: Local and global concern, in Mexico megacity: an integrated assessment, Kluwer Academic Press, The Netherlands, 2002.

Morino, Y., Kondo, Y., Takegawa, N., et al.: Partitioning of $\mathrm{HNO}_{3}$ and particulate nitrate over Tokyo: Effect of vertical mixing, J. Geophys. Res.-Atmos., 111, D15215, doi:10.1029/2005JD006887, 2006.

Nemitz, E., Jimenez, J. L., Huffman, J. A., Ulbrich, I. M., Canagaratna, M. R., Worsnop, D. R., and Guenther, A. B.: An eddycovariance system for the measurement of surface/atmosphere exchange fluxes of submicron aerosol chemical species - First application above an urban area, Aerosol Sci. Tech., 42(8), 636657, 2008

Neuman, J. A., Nowak, J. B., Brock, C. A., et al.: Variability in ammonium nitrate formation and nitric acid depletion with altitude and location over California, J. Geophys. Res.-Atmos., 108(D17), 4557, doi:10.1029/2003JD003616, 2003.

Osborn, R. J., Taylor, N. F., Spencer, C. W., and Collins, D. R.: Isolation of ambient particles of known critical supersaturation: the differential activation separator (DAS), Aerosol Sci. Tech., 42(9), 759-772, 2008.
Paatero, P. and Tapper, U.: Positive Matrix Factorization - a Nonnegative Factor Model with Optimal Utilization of ErrorEstimates of Data Values, Environmetrics, 5(2), 111-126, 1994.

Paredes-Miranda, G., Arnott, W. P., Jimenez, J. L., Aiken, A. C., Gaffney, J. S., and Marley, N. A.: Primary and secondary contributions to aerosol light scattering and absorption in Mexico City during the MILAGRO 2006 campaign, Atmos. Chem. Phys., 9, 3721-3730, 2009,

http://www.atmos-chem-phys.net/9/3721/2009/.

Pope, C. A. and Dockery, D. W.: Health effects of fine particulate air pollution: Lines that connect, J. Air Waste Manage., 56(6), 709-742, 2006.

Querol, X., Pey, J., Minguillón, M. C., Pérez, N., Alastuey, A., Viana, M., Moreno, T., Bernabé, R. M., Blanco, S., Cárdenas, B., Vega, E., Sosa, G., Escalona, S., Ruiz, H., and Artñano, B.: PM speciation and sources in Mexico during the MILAGRO-2006 Campaign, Atmos. Chem. Phys., 8, 111-128, 2008, http://www.atmos-chem-phys.net/8/111/2008/.

Salcedo, D., Onasch, T. B., Canagaratna, M. R., Dzepina, K., Huffman, J. A., Jayne, J. T., Worsnop, D. R., Kolb, C. E., Weimer, S., Drewnick, F., Allan, J. D., Delia, A. E., and Jimenez, J. L.: Technical Note: Use of a beam width probe in an Aerosol Mass Spectrometer to monitor particle collection efficiency in the field, Atmos. Chem. Phys., 7, 549-556, 2007, http://www.atmos-chem-phys.net/7/549/2007/.

Salcedo, D., Onasch, T. B., Dzepina, K., Canagaratna, M. R., Zhang, Q., Huffman, J. A., DeCarlo, P. F., Jayne, J. T., Mortimer, P., Worsnop, D. R., Kolb, C. E., Johnson, K. S., Zuberi, B., Marr, L. C., Volkamer, R., Molina, L. T., Molina, M. J., Cardenas, B., Bernabé, R. M., Márquez, C., Gaffney, J. S., Marley, N. A., Laskin, A., Shutthanandan, V., Xie, Y., Brune, W., Lesher, R., Shirley, T., and Jimenez, J. L.: Characterization of ambient aerosols in Mexico City during the MCMA-2003 campaign with Aerosol Mass Spectrometry: results from the CENICA Supersite, Atmos. Chem. Phys., 6, 925-946, 2006, http://www.atmos-chem-phys.net/6/925/2006/.

San Martini, F. M., Dunlea, E. J., Volkamer, R., Onasch, T. B., Jayne, J. T., Canagaratna, M. R., Worsnop, D. R., Kolb, C. E., Shorter, J. H., Herndon, S. C., Zahniser, M. S., Salcedo, D., Dzepina, K., Jimenez, J. L., Ortega, J. M., Johnson, K. S., McRae, G. J., Molina, L. T., and Molina, M. J.: Implementation of a Markov Chain Monte Carlo method to inorganic aerosol modeling of observations from the MCMA-2003 campaign Part II: Model application to the CENICA, Pedregal and Santa Ana sites, Atmos. Chem. Phys., 6, 4889-4904, 2006, http://www.atmos-chem-phys.net/6/4889/2006/.

Secretaria del Medio Ambiente, G.d.D.F.: Inventario de Emisiones, http://www.sma.df.gob.mx/inventario_emisiones/, 2006.

Sinha, P., Hobbs, P. V., Yokelson, R. J., Blake, D. R., Gao, S., and Kirchstetter, T. W.: Emissions from miombo woodland and dambo grassland savanna fires, J. Geophys. Res.-Atmos., 109, D11305, doi:10.1029/2004JD004521, 2004.

Slowik, J. G., Stainken, K., Davidovits, P., et al.: Particle morphology and density characterization by combined mobility and aerodynamic diameter measurements. Part 2: Application to combustion-generated soot aerosols as a function of fuel equivalence ratio, Aerosol Sci. Tech., 38(12), 1206-1222, 2004.

Stone, E. A., Snyder, D. C., Sheesley, R. J., Sullivan, A. P., Weber, R. J., and Schauer, J. J.: Source apportionment of fine organic 
aerosol in Mexico City during the MILAGRO experiment 2006, Atmos. Chem. Phys., 8, 1249-1259, 2008,

http://www.atmos-chem-phys.net/8/1249/2008/.

Sueper, D.: ToF-AMS High Resolution Analysis Software - Pika, online available at: http://cires.colorado.edu/jimenez-group/ ToFAMSResources/ToFSoftware/PikaInfo/, 2008.

Sullivan, A. P., Holden, A. S., Patterson, L. A., McMeeking, G. R., Kreidenweis, S. M., Malm, W. C., Hao, W. M., Wold, C. E., and Collett, J. L.: A method for smoke marker measurements and its potential application for determining the contribution of biomass burning from wildfires and prescribed fires to ambient $\mathrm{PM}_{2.5}$ organic carbon, J. Geophys. Res.-Atmos., 113, D22302, doi:10.1029/2008JD010216, 2008.

Takegawa, N., Miyakawa, T., Kondo, Y., Jimenez, J. L., Zhang, Q., Worsnop, D. R., and Fukuda, M.: Seasonal and diurnal variations of submicron organic aerosol in Tokyo observed using the Aerodyne aerosol mass spectrometer, J. Geophys. Res.-Atmos., 111, D11206, doi:10.1029/2005JD006515, 2006.

Takegawa, N., Miyazaki, Y., Kondo, Y., et al. Characterization of an Aerodyne Aerosol Mass Spectrometer (AMS): Intercomparison with other aerosol instruments, Aerosol Sci Tech., 39(8), 760$770,2005$.

Turpin, B. J. and Lim, H. J.: Species contributions to PM2.5 mass concentrations: Revisiting common assumptions for estimating organic mass, Aerosol Sci. Tech., 35(1), 602-610, 2001.

Ulbrich, I. M., Canagaratna, M. R., Zhang, Q., Worsnop, D. R., and Jimenez, J. L.: Interpretation of organic components from Positive Matrix Factorization of aerosol mass spectrometric data, Atmos. Chem. Phys., 9, 2891-2918, 2009,

http://www.atmos-chem-phys.net/9/2891/2009/.

Volkamer, R., Etzkorn, T., Geyer, A., and Platt, U.: Correction of the oxygen interference with UV spectroscopic (DOAS) measurements of monocyclic aromatic hydrocarbons in the atmosphere, Atmos. Environ., 32(21), 3731-3747, 1998.

Volkamer, R., Jimenez, J. L., San Martini, F., Dzepina, K., Zhang, Q., Salcedo, D., Molina, L. T., Worsnop, D. R., and Molina, M. J.: Secondary organic aerosol formation from anthropogenic air pollution: Rapid and higher than expected, Geophys Res. Lett., 33(17), L17811, doi:10.1029/2006GL026899, 2006.

Volkamer, R., Martini, F. S., Molina, L. T., Salcedo, D., Jimenez, J. L., and Molina, M. J.: A missing sink for gas-phase glyoxal in Mexico City: Formation of secondary organic aerosol, Geophys Res. Lett., 34, L19807, doi:10.1029/2007GL030752, 2007.

Volkamer, R., Molina, L. T., Molina, M. J., Shirley, T., and Brune, W. H.: DOAS measurement of glyoxal as an indicator for fast VOC chemistry in urban air, Geophys Res. Lett., 32(8), L08806, doi:10.1029/2005GL022616, 2005.

Wang, S. C. and Flagan, R. C.: Scanning Electrical Mobility Spectrometer, J. Aerosol Sci., 20(8), 1485-1488, 1989.

Watson, J. G.: Visibility: Science and regulation, J. Air Waste Manage., 52(6), 628-713, 2002.

Weber, R. J., Sullivan, A. P., Peltier, R. E., et al.: A study of secondary organic aerosol formation in the anthropogenicinfluenced southeastern United States, J. Geophys. Res.-Atmos., 112, D13302, doi:10.1029/2007JD008408, 2007.

Whiteman, C. D., Zhong, S., Bian, X., Fast, J. D., and Doran, J. C.: Boundary layer evolution and regional-scale diurnal circulations over the Mexico Basin and Mexican plateau, J. Geophys. Res.Atmos., 105(D8), 10081-10102, 2000.
Yokelson, R. J., Crounse, J. D., DeCarlo, P. F., Karl, T., Urbanski, S., Atlas, E., Campos, T., Shinozuka, Y., Kapustin, V., Clarke, A. D., Weinheimer, A., Knapp, D. J., Montzka, D. D., Holloway, J., Weibring, P., Flocke, F., Zheng, W., Toohey, D., Wennberg, P. O., Wiedinmyer, C., Mauldin, L., Fried, A., Richter, D., Walega, J., Jimenez, J. L., Adachi, K., Buseck, P. R., Hall, S. R., and Shetter, R.: Emissions from biomass burning in the Yucatan, Atmos. Chem. Phys., 9, 5785-5812, 2009, http://www.atmos-chem-phys.net/9/5785/2009/.

Yokelson, R. J., Urbanski, S. P., Atlas, E. L., Toohey, D. W., Alvarado, E. C., Crounse, J. D., Wennberg, P. O., Fisher, M. E., Wold, C. E., Campos, T. L., Adachi, K., Buseck, P. R., and Hao, W. M.: Emissions from forest fires near Mexico City, Atmos. Chem. Phys., 7, 5569-5584, 2007, http://www.atmos-chem-phys.net/7/5569/2007/.

Yu, J. Z., Cocker, D. R., Griffin, R. J., Flagan, R. C., and Seinfeld, J. H.: Gas-phase ozone oxidation of monoterpenes: Gaseous and particulate products, J. Atmos. Chem., 34(2), 207-258, 1999.

Zavala, M., Herndon, S. C., Wood, E. C., Onasch, T. B., Knighton, W. B., Marr, L. C., Kolb, C. E., and Molina, L. T.: Evaluation of mobile emissions contributions to Mexico City's emissions inventory using on-road and cross-road emission measurements and ambient data, Atmos. Chem. Phys., 9, 6305-6317, 2009, http://www.atmos-chem-phys.net/9/6305/2009/.

Zhang, Q., Alfarra, M. R., Worsnop, D. R., Allan, J. D., Coe, H., Canagaratna, M. R., and Jimenez, J. L.: Deconvolution and quantification of hydrocarbon-like and oxygenated organic aerosols based on aerosol mass spectrometry, Environ. Sci. Technol., 39(13), 4938-4952, 2005a.

Zhang, Q., Canagaratna, M. R., Jayne, J. T., Worsnop, D. R., and Jimenez, J. L.: Time- and size-resolved chemical composition of submicron particles in Pittsburgh: Implications for aerosol sources and processes, J. Geophys. Res.-Atmos., 110, D07S09, doi:10.1029/2004JD004649, 2005b.

Zhang, Q., Jimenez, J. L., Canagaratna, M. R., et al.: Ubiquity and Dominance of Oxygenated Species in Organic Aerosols in Anthropogenically - Influenced Northern Hemisphere Mid-latitudes, Geophys. Res. Lett., 34(13), L13801, doi:10.1029/2007GL029979, 2007a.

Zhang, Q., Jimenez, J. L., Worsnop, D. R., and Canagaratna, M.: A case study of urban particle acidity and its influence on secondary organic aerosol, Environ. Sci. Technol., 41(9), 32133219, $2007 \mathrm{~b}$.

Zhang, Q., Worsnop, D. R., Canagaratna, M. R., and Jimenez, J. L.: Hydrocarbon-like and oxygenated organic aerosols in Pittsburgh: insights into sources and processes of organic aerosols, Atmos. Chem. Phys., 5, 3289-3311, 2005c,

http://www.atmos-chem-phys.net/5/3289/2005/.

Zhao, J. and Zhang, R. Y.: Proton transfer reaction rate constants between hydronium ion $\left(\mathrm{H}_{3} \mathrm{O}(+)\right)$ and volatile organic compounds, Atmos. Environ., 38, 2177-2185, doi:10.1016/j.atmosenv.2004.01.019, 2004.

Zheng, J., Zhang, R., Fortner, E. C., Volkamer, R. M., Molina, L., Aiken, A. C., Jimenez, J. L., Gaeggeler, K., Dommen, J., Dusanter, S., Stevens, P. S., and Tie, X.: Measurements of $\mathrm{HNO}_{3}$ and $\mathrm{N}_{2} \mathrm{O}_{5}$ using ion drift-chemical ionization mass spectrometry during the MILAGRO/MCMA-2006 campaign, Atmos. Chem. Phys., 8, 6823-6838, 2008,

http://www.atmos-chem-phys.net/8/6823/2008/. 